Research Article

\title{
Seismic Behavior of Nonductile RC Frame Slotted with Corrugated Steel Plate Shear Walls
}

\author{
Ningning Feng $\mathbb{D}^{1,2}$ and Changsheng $W u \mathbb{D}^{1}$ \\ ${ }^{1}$ Department of Civil and Architecture Engineering, Changzhou Institute of Technology, Changzhou 213032, China \\ ${ }^{2}$ School of Engineering, University of British Columbia, Okanagan, BC, Canada \\ Correspondence should be addressed to Ningning Feng; fengningning1104@163.com
}

Received 22 October 2020; Revised 14 February 2021; Accepted 17 March 2021; Published 30 March 2021

Academic Editor: Hanbing Bian

Copyright (c) 2021 Ningning Feng and Changsheng Wu. This is an open access article distributed under the Creative Commons Attribution License, which permits unrestricted use, distribution, and reproduction in any medium, provided the original work is properly cited.

\begin{abstract}
Two specimens of nonductile reinforced concrete (RC) frame (ND-1) and nonductile RC frame retrofitted by corrugated steel plate shear walls slotted with columns (ND-2) are established by finite element. These specimens have same dimensions and steel skeletons. Finite element models had been verified by the existing experimental results. The hysteresis curves, skeleton curves, ductility, and stiffness curves of Specimen ND-1 and Specimen ND-2 are compared. The results show that the reinforcement effect is significant. Twenty-four models are built to study the seismic behavior on different influence parameters. The parameters are slit width, thickness of corrugated steel plate shear walls, concrete strength of nonductile RC frame, and boundary conditions of corrugated steel plate shear walls at slotted parts. The results indicate that the strength is declined with the increase of slit width. With the increase of thickness and concrete strength, the strength and stiffness are enhanced. The strength is larger with the boundary than without. Slit width and thickness have an important impact on the stiffness. Concrete strength and boundary conditions have little impact on stiffness. The strengthened nonductile RC frames have enough ductility.
\end{abstract}

\section{Introduction}

In earthquake zones of China, there were number of older, low-rise concrete buildings which have not been retrofitted for earthquake safety. These two-storey to five-storey structures may meet the old building-code standards. However, new building codes reflected later earthquake engineering research and incorporated structural elements that allowed concrete buildings to bend and stretch a bit during earthquakes. Older designs were short of those details. There were hundreds of thousands of buildings that have not been retrofitted. Those brittle buildings were called "nonductile RC" buildings. "Ductile" meant flexible, while "reinforced concrete" refers to concrete embedded with material such as steel mesh and rebar. From an earthquake point of view, nonductile RC frames were lack of ductility and energy dissipation.
Some scholars [1-9] have studied the seismic performance of nonductile frame structures and corrugated steel plate shear walls. Wu et al. [10] developed a multiscale model of nonductile frame. The hysteresis curves and skeleton curves of nonductile frame were analyzed by the developed model. The results showed that the multiscale model can simulate the boundary conditions of concrete components. Sae-Long et al. [11] proposed a fiber frame element for nonductile RC columns. The results revealed the essence of inclusion of shear response and shear flexure interaction. Shoraka et al. [12] introduced advanced analytical models to simulate the nonlinear dynamic response of nonductile $\mathrm{RC}$ structures. It estimated the expected losses of existing nonductile concrete buildings considering their vulnerability to collapse. The results showed that collapse did not occur in low earthquake shaking intensities and losses were dominated by nonstructural damage. It was effective to use the method of earthquake vulnerability. 
On the basic of the researches, it was necessary to reinforce nonductile RC frame structures. At present, there were two main forms of reinforcements. One was steel bracing, and another one was carbon fiber reinforced plastic (CFRP). Song et al. [13] proposed shape memory alloy (SMA) braces. The nonlinear dynamic analyses and hysteresis performance of the SMA braces were studied. The results indicated that SMA braces strengthening nonductile concrete structures dissipated earthquake energy effectively. Khampanit [14] researched bucklingrestrained braces reinforcing nonductile RC frames. An experiment and numbers of dynamic analyses were carried to verify the effectiveness of buckling-restrained braces. The researchers showed that this kind of braces enhanced stiffness, lateral force capacity, and energy dissipation of nonductile RC frames. Sarno and Manfredi [15] studied buckling-restrained braces (BRBs) to reinforce nonductile RC frames. Seven code-compliant natural earthquake records were selected and employed to perform inelastic response history analyses at serviceability. The results of analysis indicated that more than $60 \%$ of input seismic energy was dissipated by the BRBs at ultimate limit states. Chen et al. [16] conducted a study on a 1/2 scale two-span and two-storey specimen. The experiment was to research CFRP reinforced nonductile RC frames. The results showed that the average displacement ductility factor of retrofitted RC frame is 2.81 . There was a large safety stock space when the maximum storey drift ratio reaches $1 / 50$. Lv et al. [17] considered three reinforcement schemes about fiber reinforced polymer (FRP) rehabilitation. It compared seismic collapse fragilities between nonductile RC frames and reinforced specimens. The results showed that FRP rehabilitation scheme strengthening the entire structure promoted the seismic collapse resistance effectively.

The objective of this research is to study the reinforcement effect of corrugated steel plate shear walls slotted with columns. The paper changed parameter types (such as slit width, thickness, concrete strength, and boundary conditions) and compared seismic performance at different conditions.

The significance of this research is to propose corrugated steel plate shear walls reinforcing nonductile RC frames, which were separated with columns. The corrugated steel plate shear walls generate large oblique tension after buckling. This force extends to the surrounding RC beam and column members. The columns will bear the resulting transverse tension. As a result, the corresponding additional bending stress was generated in RC columns. To avoid the negative effect of steel plate tension belt on the RC frame columns, the corrugated steel plate shear was slotted with columns and connected with beams only.

\section{Establishment of Nonductile RC Frame}

2.1. Specimens Design. Two specimens of nonductile RC frame (ND-1, $\mathrm{N}$ is present non; $D$ is present ductile) and nonductile RC frame retrofitted by corrugated steel plate shear walls slotted with columns (ND-2) were designed with the same dimensions and steel skeletons as shown in Figure 1 . The reduced scale was $1 / 2$. The clear span was $2.7 \mathrm{~m}$, storey height was $1.8 \mathrm{~m}$, and the total height was $2.65 \mathrm{~m}$. The cross sections of column and beams were $180 \times 200 \mathrm{~mm}$, $150 \times 250 \mathrm{~mm}$, and $400 \times 400 \mathrm{~mm}$, respectively. The specimens were designed as nonductile frames. One of the standards about nonductile frame was insufficient transversal ties. Hence, it did not consider the joint area with dense transversal ties reinforcement.

Specimen ND-2 was reinforced by corrugated steel plate shear walls. The layout of corrugated steel plate shear walls is shown in Figure 2. The selected slit width was $10 \mathrm{~mm}$. Corrugated steel plate shear walls were arranged on both sides of the frame. Corrugated steel plate shear walls were connected with beams using angle steel and tapping screws. The slabs of two pieces of corrugated steel plate shear walls were distributed as the shape of "X". As the reason of the limitation of plate width, rivets were adopted to connect two corrugated steel plate shear walls.

The connection method of corrugated steel plate shear walls and beams meets the demand of practical engineering. To research the influence of various factors of slotting with columns, the study of corrugated steel plate shear walls reinforced method is at the stage of finite element analysis at present.

2.2. Materials. Concrete average compressive strength was $30 \mathrm{MPa}$. The elasticity modulus of concrete was $30000 \mathrm{MPa}$. The diameter of longitudinal bars was $10 \mathrm{~mm}$. Yield strength was $400 \mathrm{MPa}$. The diameter of transversal ties was $6 \mathrm{~mm}$. Yield strength was $235 \mathrm{MPa}$. The elasticity modulus of longitudinal bars was $200000 \mathrm{MPa}$. The elasticity modulus of transversal ties was $210000 \mathrm{MPa}$. The yield strength corrugated steel plate of YX21-180-900 with $0.6 \mathrm{~mm}$ thickness was $264 \mathrm{MPa}$. Cross section dimensions of corrugated steel plate are shown in Figure 3. The properties of concrete, longitudinal bars, transversal ties, and corrugated steel plate are summarized in Table 1.

2.3. Loading Program and Boundary Conditions. The vertical load applied to the two columns was $51.48 \mathrm{kN}$. Axial compression ratio was $\mathrm{N} / f_{\mathrm{c}} \mathrm{A}=0.1$. Low cyclic loads were applied at the end of the beam and the loading program can be seen in Figure 4. The loading program was as per Qiu [18]. It indicated that one of the load rules was displacement-controlled loading. This load rule was also suitable for simulation. Considering the convergence of models, each load step had one cycle at a time. The bottom of two columns was rigid coupling. Vertical loads were applied as the form of area loads. The beam end was coupled for cycle loading.

The element of reinforced concrete is SOLID 65. The steel bars are dispersed in the concrete. The element of corrugated steel plate shear wall is SHEEL 181. The contact between elements is via the common nodes by cutting. The model is $3 \mathrm{D}$. The boundary conditions at the base of the corrugated plates are solid joint. 


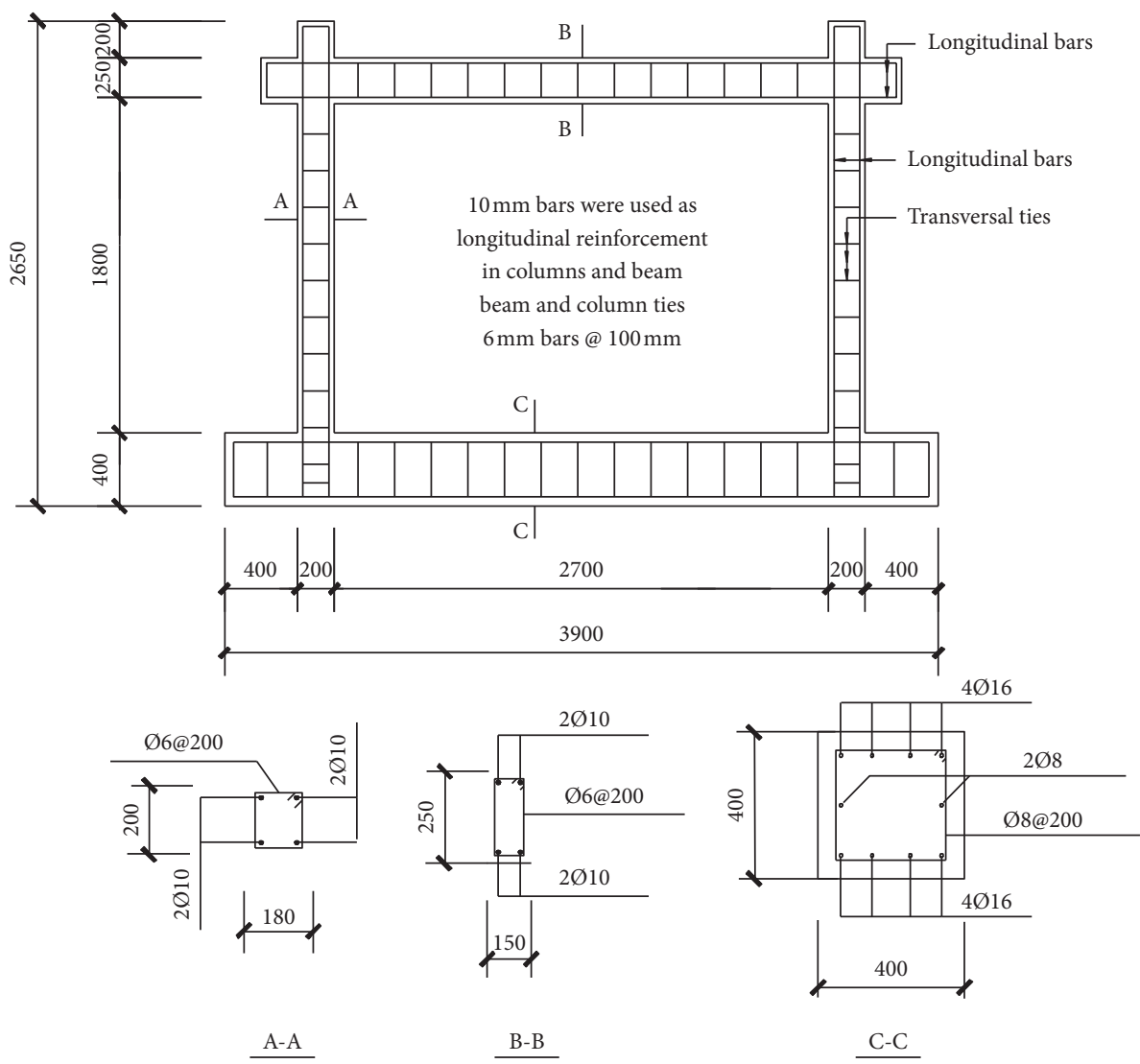

Figure 1: Steel skeletons.

2.4. Constitutive Model. On the basis of existing research, our team had published [19] about the material modes including concrete model, steel bar model, and corrugated steel plate model. The concrete model had an ascending part and descending part, which are shown in Figure 5. The steel bar and steel plate model was divided into two straight lines. In other words, the stress was close to ideal plasticity in a large deformation after reaching the yield strength. Steel bar and corrugated steel plate model are shown in Figure 6.

2.5. Verification of Finite Element Models. Our team [19] had verified the finite element model through comparing the hysteretic curves and skeleton curves of experimental and finite element results. The deviation of peak loads was $0.88 \%$ and $1.92 \%$, respectively.

2.6. Finite Element Modeling of Nonductile RC Frame. Based on the verification of finite element models, the paper established the seismic behavior of nonductile RC frame retrofitted by corrugated steel plate shear walls slotted with columns only. The nonductile RC frame (ND-1) and the reinforced frame (ND-2) are shown in Figures 7(a) and 7(b). Slit width of Specimen ND-2 was $10 \mathrm{~mm}$.

\section{Analysis Results}

3.1. Strength and Ductility. The hysteretic curves and skeleton curves of Specimen ND-1 and Specimen ND-2 are shown in Figures 8 and 9. The yield load, ultimate load, displacements, and ductility can be seen in Table 2. It indicated that the strength had been improved $100.76 \%$ when the nonductile RC frame was strengthened with corrugated steel plate shear walls. The ductility was improved from 2.86 to 3.67 .

3.2. Stiffness. The stiffness curves of Specimen ND-1 and Specimen ND-2 are shown in Figure 10. The initial stiffness and ultimate stiffness can be seen in Table 3 . It showed that the initial stiffness and ultimate stiffness had been enhanced by $63.85 \%$ and $38.26 \%$. The stiffness had been improved greatly.

3.3. Energy Dissipating Capacity. The accumulated energy dissipation curves of Specimen ND-1 and Specimen ND-2 are shown in Figure 11. It showed that the accumulated energy dissipation of Specimen ND-1 and Specimen ND-2 was $1602.26 \mathrm{kN} \mathrm{mm}$ and $10138.14 \mathrm{kN} \mathrm{mm}$. The energy dissipation improved by $84.20 \%$. 


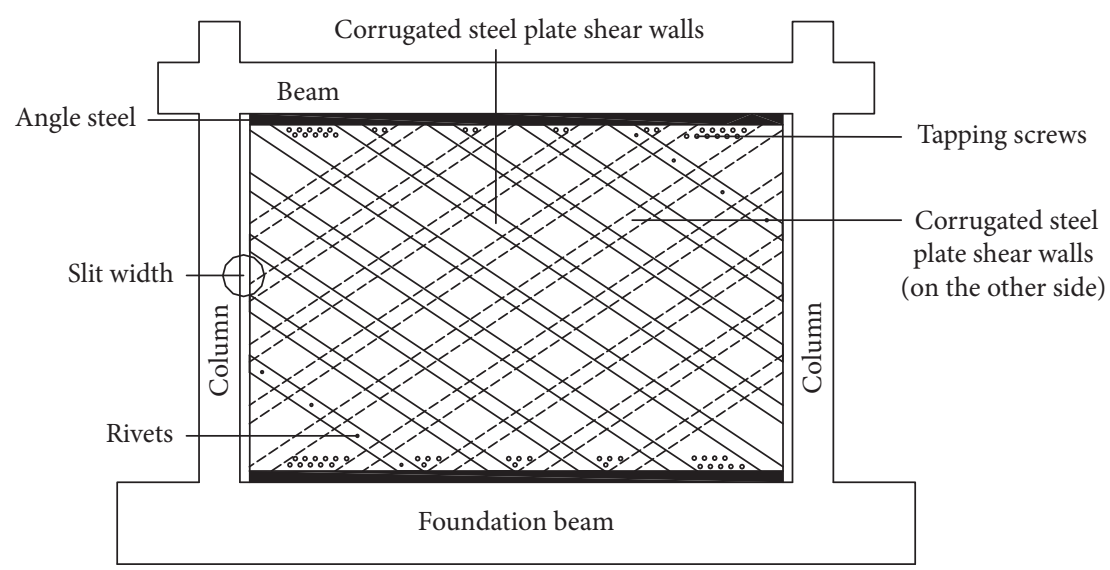

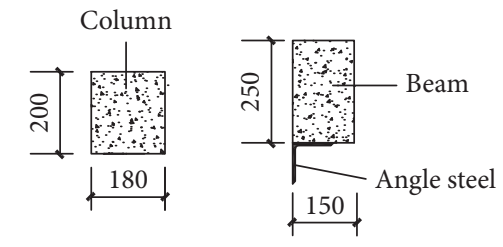

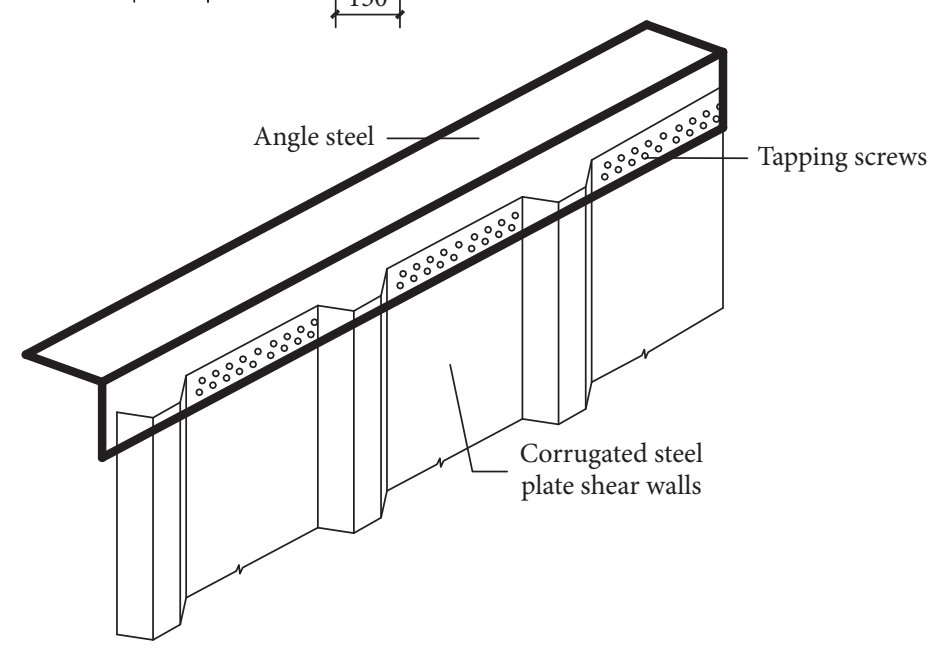

FIgURe 2: Arrangement diagram.

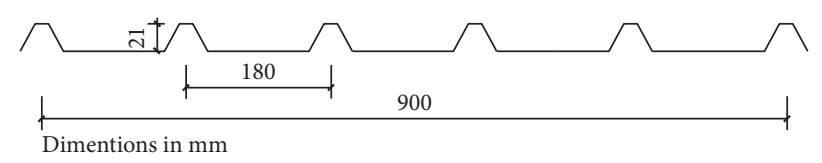

Figure 3: Cross section dimensions of corrugated steel plate.

TABLE 1: Material properties. 


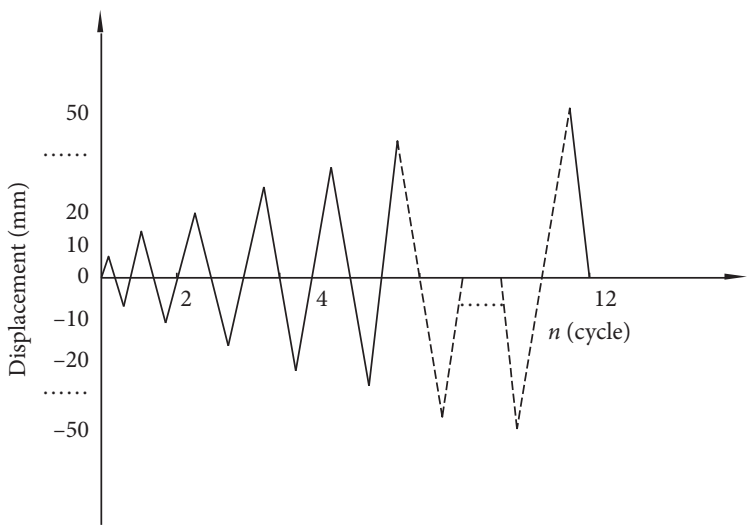

FIGURE 4: Loading program.

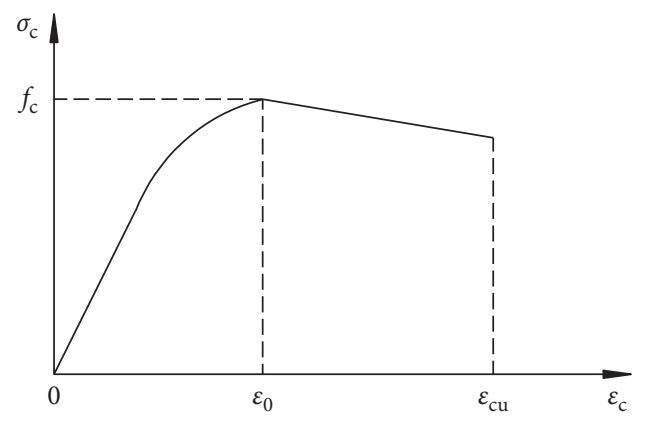

Figure 5: Concrete model.

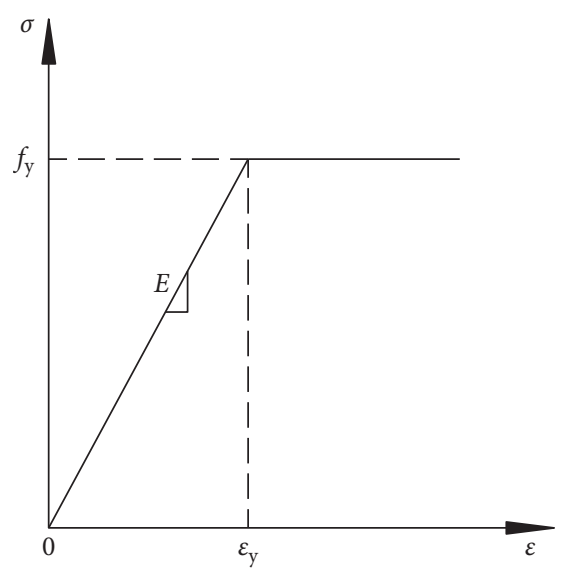

Figure 6: Steel bar and corrugated steel plate model.

\section{Parameters Analysis}

The paper discussed 24 specimens (ND-1-ND-24) in different influence parameters. The influence parameters are listed in Table 4. It can be seen from the table that the slit width was composed of $5 \mathrm{~mm}, 10 \mathrm{~mm}, 20 \mathrm{~mm}, 30 \mathrm{~mm}$, $40 \mathrm{~mm}, 60 \mathrm{~mm}, 100 \mathrm{~mm}, 200 \mathrm{~mm}, 300 \mathrm{~mm}$, and $400 \mathrm{~mm}$. The selected slit width was on the basis of Zhao [20] team research. The thickness of corrugated steel plate shear walls was divided into $0.4 \mathrm{~mm}, 0.6 \mathrm{~mm}$, and $0.8 \mathrm{~mm}$. The selected thickness was in the light of experiments and finite element analysis $[19,21]$. The concrete compressive strength of nonductile RC frame was $30 \mathrm{MPa}, 40 \mathrm{MPa}, 50 \mathrm{MPa}$, and $60 \mathrm{MPa}$, respectively. Boundary conditions of corrugated steel plate shear walls at slotted parts were divided into two parts: Z-direction constraint and without constraint. 


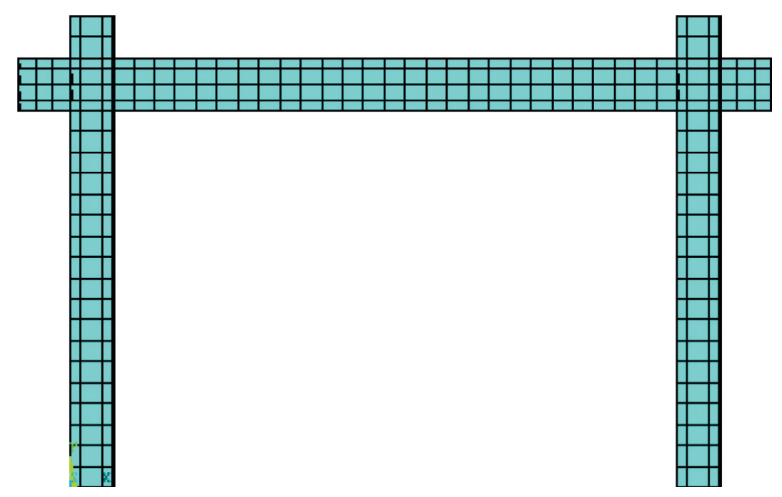

(a)
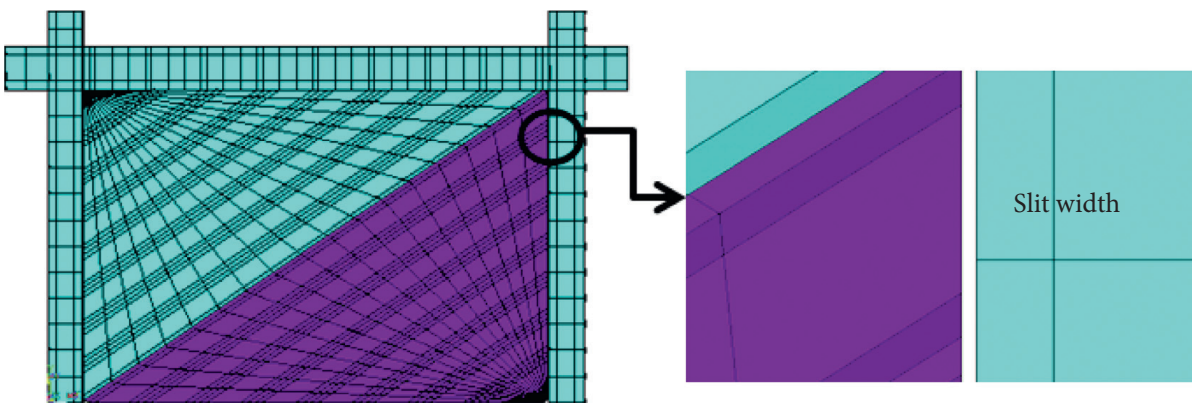

(b)

FIgure 7: Finite element models. (a) Nonductile RC frame (ND-1). (b) Reinforced frame (ND-2) with slit width (10 mm).

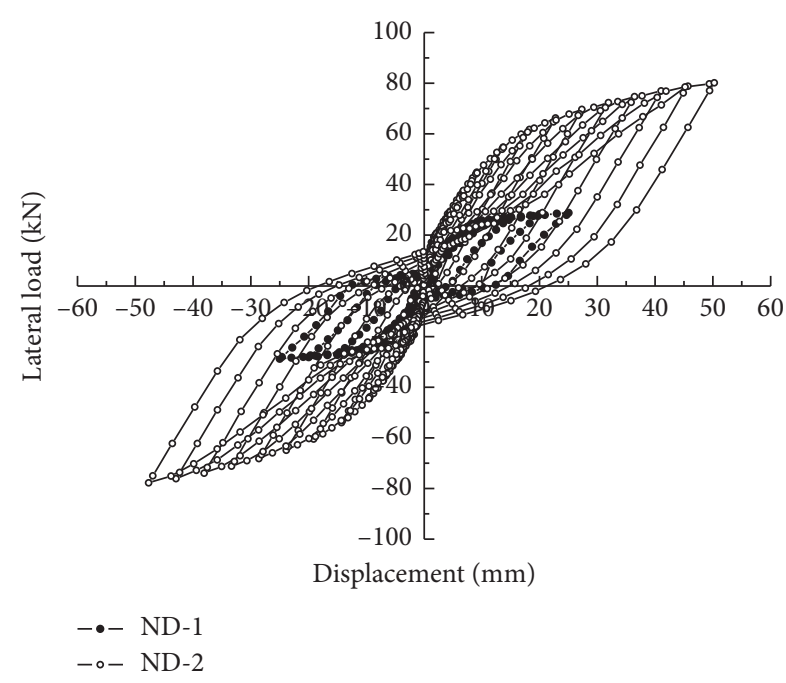

FIGURE 8: Hysteretic curves.

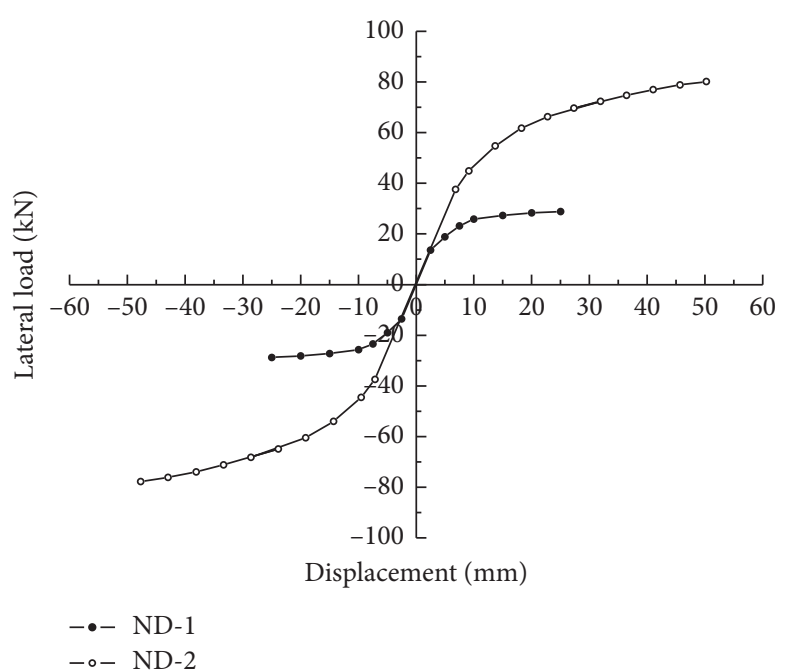

FIGURE 9: Skeleton curves.

\section{Discussion}

Hysteretic curves, skeleton curves, ductility, and stiffness are discussed in this section. The influence parameters are slit width, thickness, concrete strength, and boundary conditions. As can be seen in Table 4, the paper selected ND-2, ND-16, ND-18, and ND-24 corresponding slit widths $10 \mathrm{~mm}, 100 \mathrm{~mm}, 200 \mathrm{~mm}$, and $400 \mathrm{~mm}$ to analyze the influence of slit width on the whole structure. Specimens ND-1, ND-2, ND-3, ND-15, ND-16, and ND-17 were selected to compare the influence of thickness. Specimens ND-11, ND-12, ND-13, ND-14, ND-18, ND-19, ND-20, and ND-21 were chosen to compare the effect of concrete strength of the structure. Boundary conditions of corrugated steel plate edge at slotted parts were related Specimens ND-5, ND-6, ND-7, ND-8, ND-9, ND-10, ND-22, and ND-23. The selected slit width was on the basis of Zhao [20] team research. The thickness of corrugated steel plate shear walls was divided into $0.4 \mathrm{~mm}, 0.6 \mathrm{~mm}$, and $0.8 \mathrm{~mm}$. The selected thickness was in the light of experiments and 
TABLE 2: Loads, displacement, and ductility.

\begin{tabular}{lcccccc}
\hline Specimen & Slit width $(\mathrm{mm})$ & Yield load $(\mathrm{kN})$ & $\Delta_{\mathrm{y}}(\mathrm{mm})$ & Ultimate load $(\mathrm{kN})$ & $\Delta_{\mathrm{u}}(\mathrm{mm})$ & Ductility \\
\hline ND-1 & - & 23.95 & 8.76 & 28.86 & 25.03 \\
ND-2 & 10 & 54.72 & 13.69 & 80.10 & 2.86 \\
\hline
\end{tabular}

$\Delta_{\mathrm{y}}:$ yield displacement; $\Delta_{\mathrm{u}}$ : ultimate load.

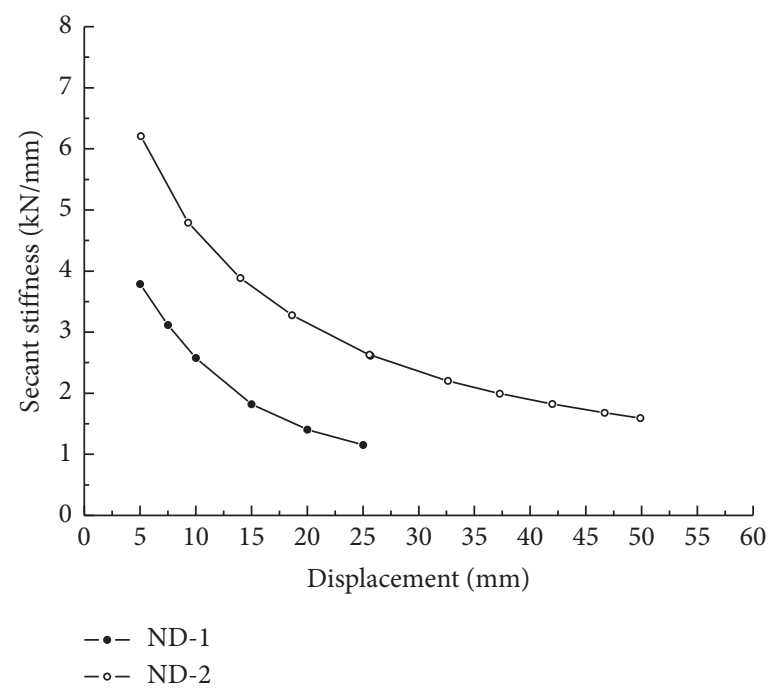

Figure 10: Stiffness curves.

TABLE 3: Initial stiffness and ultimate stiffness.

\begin{tabular}{lccc}
\hline Specimen & Slit width $(\mathrm{mm})$ & Initial stiffness $(\mathrm{kN} / \mathrm{mm})$ & Ultimate stiffness $(\mathrm{kN} / \mathrm{mm})$ \\
\hline ND-1 & - & 3.79 & 1.15 \\
ND-2 & 10 & 6.21 & 1.59 \\
\hline
\end{tabular}

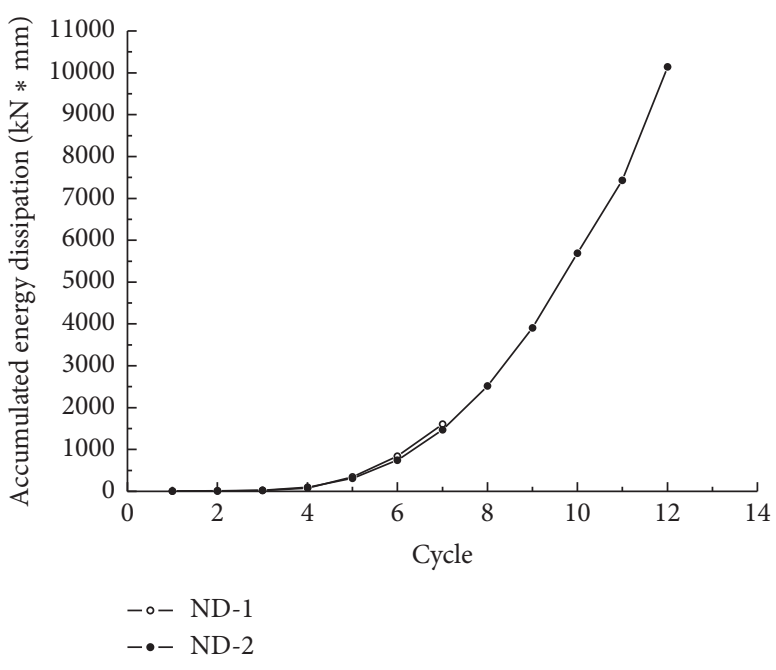

Figure 11: Accumulated energy dissipation.

finite element analysis [19, 21]. The reason for selecting big difference slit width was to contrastively analyze the mechanical property under the big difference slit width from Section 5.1 to Section 5.4.

\subsection{Slit Width}

5.1.1. Hysteretic Curves. The hysteretic curves of different slit width are shown in Figures 12(a)-12(d). It can be seen from the figures that the hysteretic curves were not full while the slit width was larger. In the other words, the plump degree declined with the increase of corrugated steel plate width. It manifested that corrugated steel plate shear walls slotted with columns could achieve good dissipation capacity. When the slit width was within the scope of $200 \mathrm{~mm}$, the energy dissipating could gain good performance.

5.1.2. Skeleton Curves. The skeleton curves of different slit width are shown in Figure 13. Loads, displacement, and ductility of different slit width are listed in Table 5. The skeleton curves had the same trend. Because of the convergence of finite element models, the paper compared different strength under the displacement of about $50 \mathrm{~mm}$. The skeleton curves derived from the maximum load and displacement of each hysteretic loop and the yield loads and ultimate loads are listed in Table 3. It can be derived from the table that the ultimate loads were $80.10 \mathrm{kN}, 56.73 \mathrm{kN}$, $50.27 \mathrm{kN}$, and $38.48 \mathrm{kN}$ and the corresponding slit widths 
TABLE 4: Influence parameters.

\begin{tabular}{|c|c|c|c|c|}
\hline Specimens & Slit width $(\mathrm{mm})$ & Thickness (mm) & Concrete strength $(\mathrm{MPa})$ & Boundary conditions \\
\hline ND-1 & \multirow{3}{*}{5} & 0.4 & \multirow{3}{*}{30} & \multirow{3}{*}{ - } \\
\hline ND-2 & & 0.6 & & \\
\hline ND-3 & & 0.8 & & \\
\hline ND-2 & 10 & 0.6 & 30 & - \\
\hline ND-5 & \multirow{2}{*}{20} & \multirow{2}{*}{0.6} & \multirow{2}{*}{30} & UZ \\
\hline ND-6 & & & & - \\
\hline ND-7 & \multirow{2}{*}{30} & \multirow{2}{*}{0.6} & \multirow{2}{*}{30} & $\mathrm{UZ}$ \\
\hline ND-8 & & & & - \\
\hline ND-9 & \multirow{2}{*}{40} & \multirow{2}{*}{0.6} & \multirow{2}{*}{30} & UZ \\
\hline ND-10 & & & & 一 \\
\hline ND-11 & \multirow{4}{*}{60} & \multirow{4}{*}{0.6} & 30 & \multirow{4}{*}{-} \\
\hline ND-12 & & & 40 & \\
\hline ND-13 & & & 50 & \\
\hline ND-14 & & & 60 & \\
\hline ND-15 & \multirow{3}{*}{100} & 0.4 & \multirow{3}{*}{30} & \multirow{3}{*}{-} \\
\hline ND-16 & & 0.6 & & \\
\hline ND-17 & & 0.8 & & \\
\hline ND-18 & \multirow{4}{*}{200} & \multirow{4}{*}{0.6} & 30 & \multirow{4}{*}{-} \\
\hline ND-19 & & & 40 & \\
\hline ND-20 & & & 50 & \\
\hline ND-21 & & & 60 & \\
\hline ND-22 & \multirow{2}{*}{300} & \multirow{2}{*}{0.6} & \multirow{2}{*}{30} & UZ \\
\hline ND-23 & & & & - \\
\hline ND-24 & 400 & 0.6 & 30 & - \\
\hline
\end{tabular}

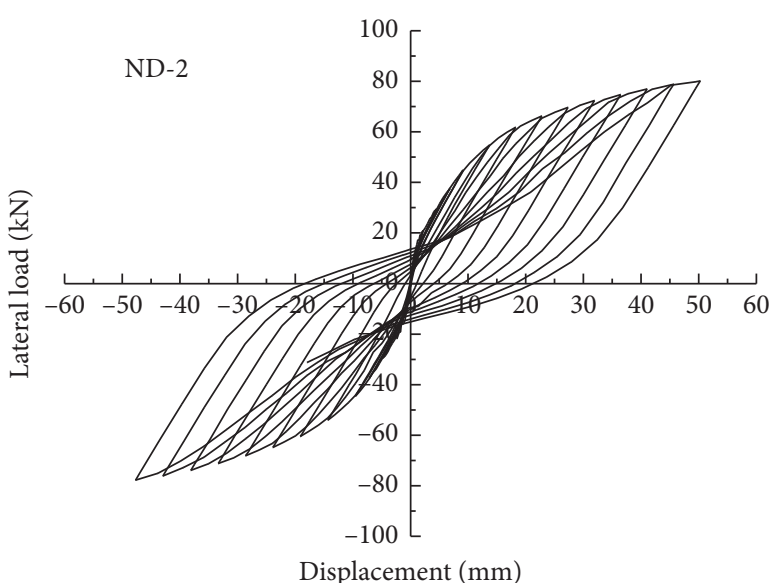

(a)

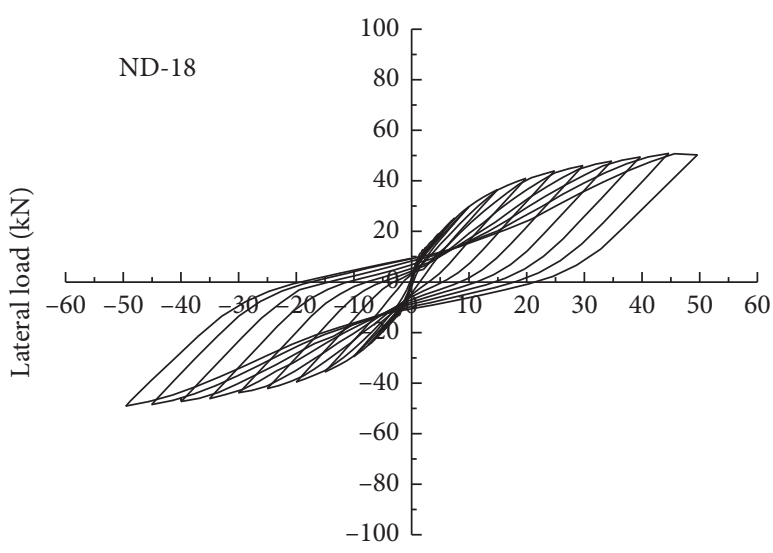

Displacement (mm)

(c)

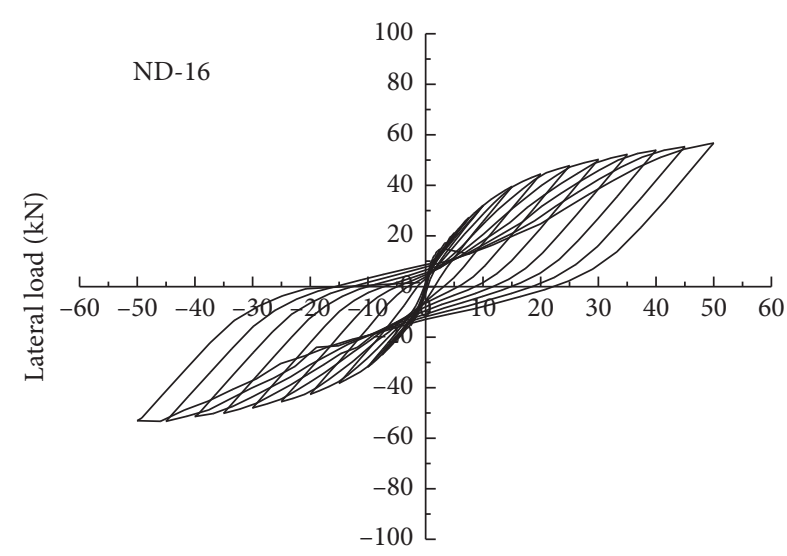

Displacement (mm)

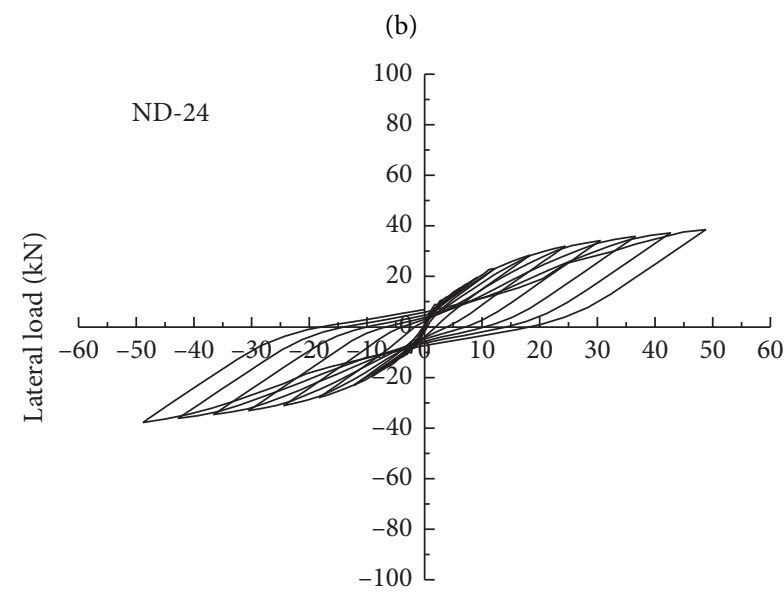

Displacement $(\mathrm{mm})$

(d)

FIGURE 12: Hysteretic curves of different slit width. (a) $10 \mathrm{~mm}$. (b) $100 \mathrm{~mm}$. (c) $200 \mathrm{~mm}$. (d) $400 \mathrm{~mm}$. 


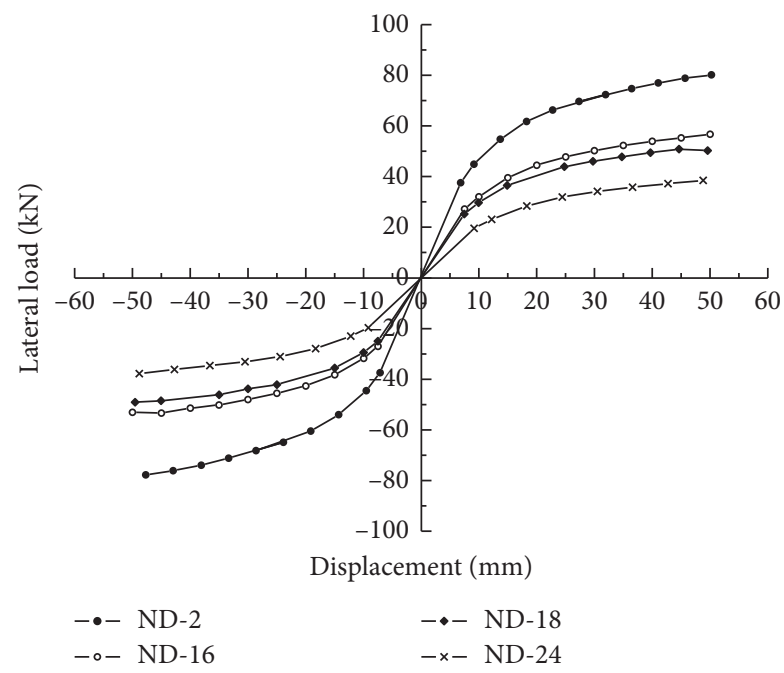

FIGURE 13: Skeleton curves of different slit width.

TABLE 5: Loads, displacement, and ductility of different slit width.

\begin{tabular}{|c|c|c|c|c|c|c|}
\hline Specimen & Slit width $(\mathrm{mm})$ & Yield load $(\mathrm{kN})$ & $\Delta_{y}(\mathrm{~mm})$ & Ultimate load $(\mathrm{kN})$ & $\Delta_{u}(\mathrm{~mm})$ & Ductility \\
\hline ND-2 & 10 & 54.72 & 13.69 & 80.10 & 50.25 & 3.67 \\
\hline ND-16 & 100 & 39.56 & 15.23 & 56.73 & 50.01 & 3.28 \\
\hline ND-18 & 200 & 37.86 & 15.22 & 50.27 & 49.57 & 3.26 \\
\hline ND-24 & 400 & 26.07 & 15.34 & 38.48 & 48.80 & 3.18 \\
\hline
\end{tabular}

$\Delta_{y}$ : yield displacement; $\Delta_{u}$ : ultimate load.

were $10 \mathrm{~mm}, 100 \mathrm{~mm}, 200 \mathrm{~mm}$, and $400 \mathrm{~mm}$, respectively. The strength declined witg the increase of the slit width.

5.1.3. Ductility. The ductility of different slit width can be seen in Table 5. The ductility was $3.67,3.28,3.26$, and 3.18, respectively. The value of ductility was above 3.0 , which indicated that nonductile $\mathrm{RC}$ frame retrofitted by corrugated steel plate shear walls slotted with columns gained enough ductility.

5.1.4. Stiffness Curves. The stiffness curves of different slit width are presented in Figure 14. The initial stiffness and ultimate stiffness of different slit width are presented in Table 6 . When the slit width was $10 \mathrm{~mm}$, the structure gained greater initial stiffness. When the slit width was in the scope of $100 \mathrm{~mm}-200 \mathrm{~mm}$, the stiffness was closely relatively and decreased somewhat. The initial stiffness decreased largely when the slit width changed into $400 \mathrm{~mm}$.

\subsection{Thickness}

5.2.1. Hysteretic Curves. The paper selected slit widths $5 \mathrm{~mm}$ and $100 \mathrm{~mm}$ to investigate the influence of thickness. The thicknesses were $0.4 \mathrm{~mm}, 0.6 \mathrm{~mm}$, and $0.8 \mathrm{~mm}$. The hysteretic curves of slit widths $5 \mathrm{~mm}$ and $100 \mathrm{~mm}$ are shown in Figures 15(a)-15(c) and 16(a)-16(c). Figures showed that the strength was improved with the increase of thickness.

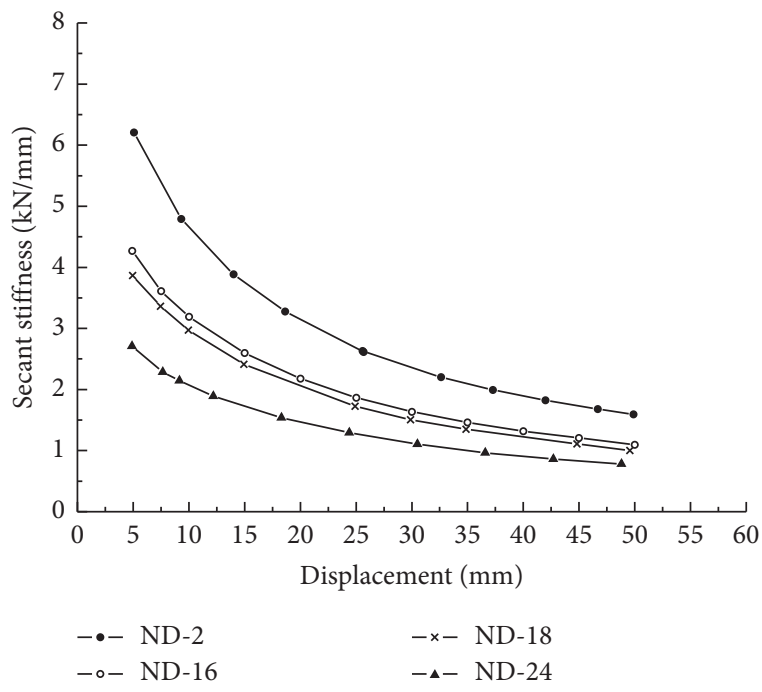

Figure 14: Stiffness curves of different slit width.

The energy dissipation had been enhanced when the thickness increased.

5.2.2. Skeleton Curves. The skeleton curves of slit widths $5 \mathrm{~mm}$ and $100 \mathrm{~mm}$ are shown in Figures 17 and 18. Loads, displacement, and ductility of different thickness are listed in Table 7 . When the slit width was $5 \mathrm{~mm}$, the ultimate loads of 
TABLE 6: Stiffness of different slit width.

\begin{tabular}{lccc}
\hline Specimen & Slit width $(\mathrm{mm})$ & Initial stiffness $(\mathrm{kN} / \mathrm{mm})$ & Ultimate stiffness $(\mathrm{kN} / \mathrm{mm})$ \\
\hline ND-2 & 10 & 6.21 & 1.59 \\
ND-16 & 100 & 4.27 & 1.10 \\
ND-18 & 200 & 3.87 & 1.01 \\
ND-24 & 400 & 2.71 & 0.78 \\
\hline
\end{tabular}

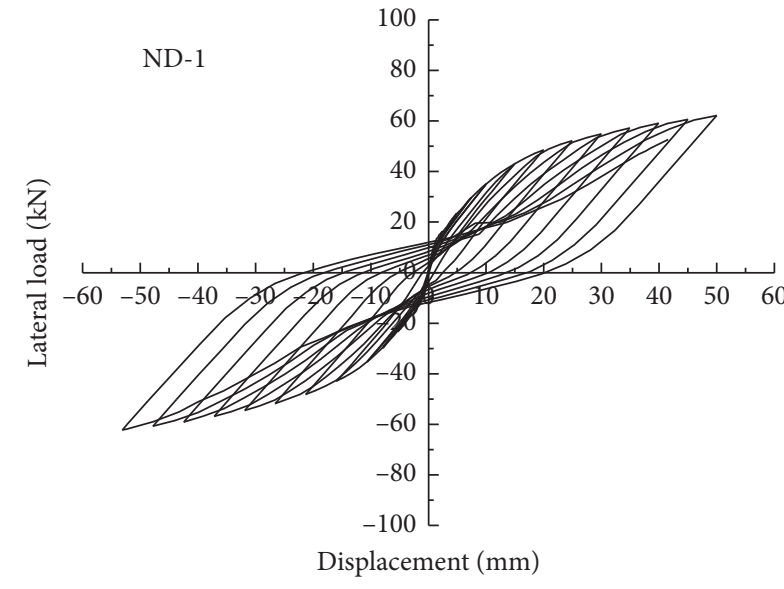

(a)

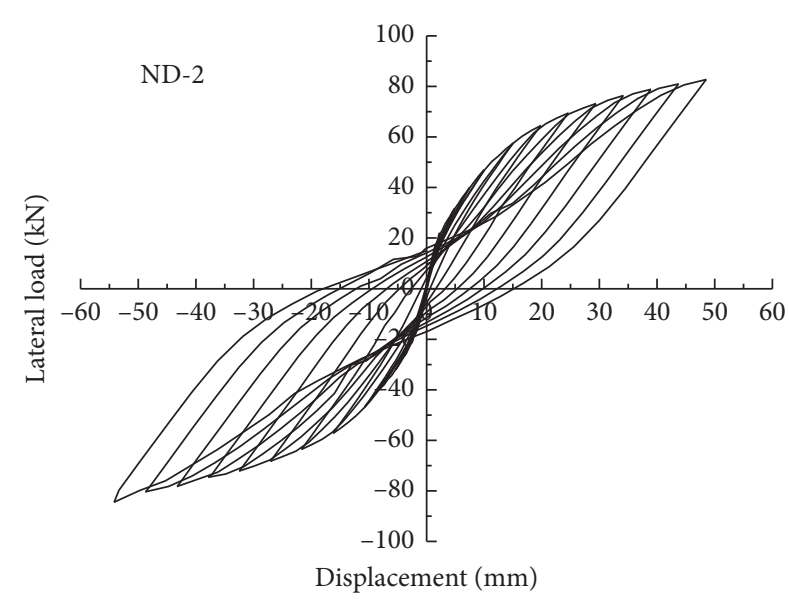

(b)

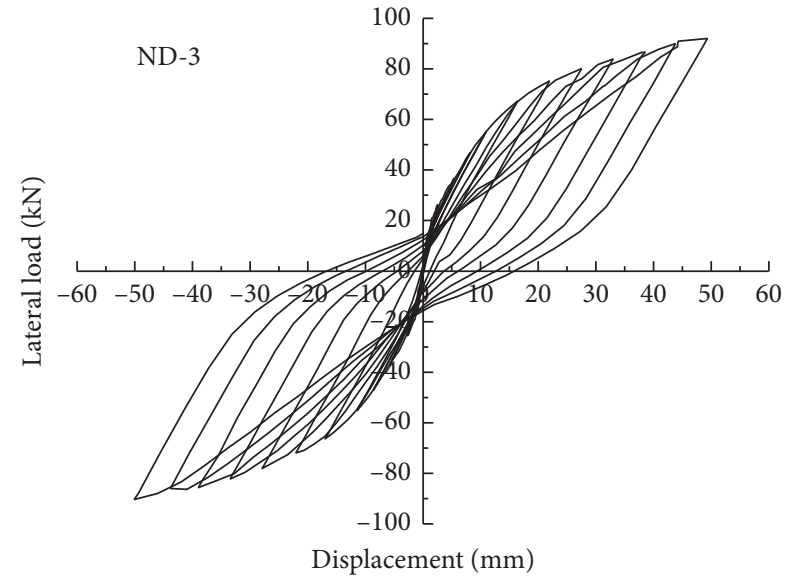

(c)

FIgURe 15: Hysteretic curves of slit width $5 \mathrm{~mm}$. (a) $0.4 \mathrm{~mm}$. (b) $0.6 \mathrm{~mm}$. (c) $0.8 \mathrm{~mm}$.

thickness $0.6 \mathrm{~mm}$ and $0.8 \mathrm{~mm}$ were improved by $34.15 \%$ and $53.03 \%$ compared to that of thickness $0.4 \mathrm{~mm}$, respectively. When the slit width was $100 \mathrm{~mm}$, the ultimate loads of thicknesses $0.6 \mathrm{~mm}$ and $0.8 \mathrm{~mm}$ were improved by $44.20 \%$ and $78.55 \%$ compared to that of thickness $0.4 \mathrm{~mm}$, respectively.

5.2.3. Ductility. The ductility of different thickness can be seen in Table 7. It can be seen from the table that the ductility was enhanced with the increase of thickness. When the slit width was $5 \mathrm{~mm}$, the ductility was from 4.19 to 4.52 . When the slit width was $100 \mathrm{~mm}$, the ductility was from 3.24 to 3.34. It indicated that the space between the columns and corrugated steel plate shear walls worked and gained good ductility. The columns were protected from the additional bending moment and axial force of corrugated steel plate shear walls.

5.2.4. Stiffness Curves. The stiffness curves of slit width $5 \mathrm{~mm}$ and $100 \mathrm{~mm}$ are presented in Figures 19 and 20. The initial stiffness and ultimate stiffness of different thickness are presented in Table 8 . The thickness $0.8 \mathrm{~mm}$ obtained larger stiffness than thickness $0.6 \mathrm{~mm}$ and $0.4 \mathrm{~mm}$. Initial stiffness of thickness $0.6 \mathrm{~mm}$ was improved by $35.50 \%$ and $45.73 \%$ than that of thickness $0.4 \mathrm{~mm}$. Initial stiffness of thickness $0.8 \mathrm{~mm}$ was improved by $44.59 \%$ and $89.41 \%$ than that of thickness $0.4 \mathrm{~mm}$. It showed that nonductile RC frame retrofitted by corrugated steel plate shear walls slotted 


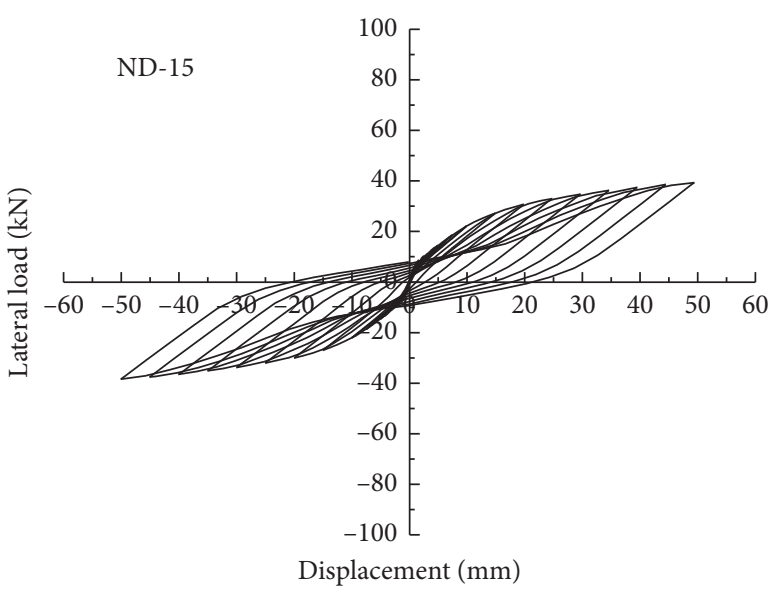

(a)

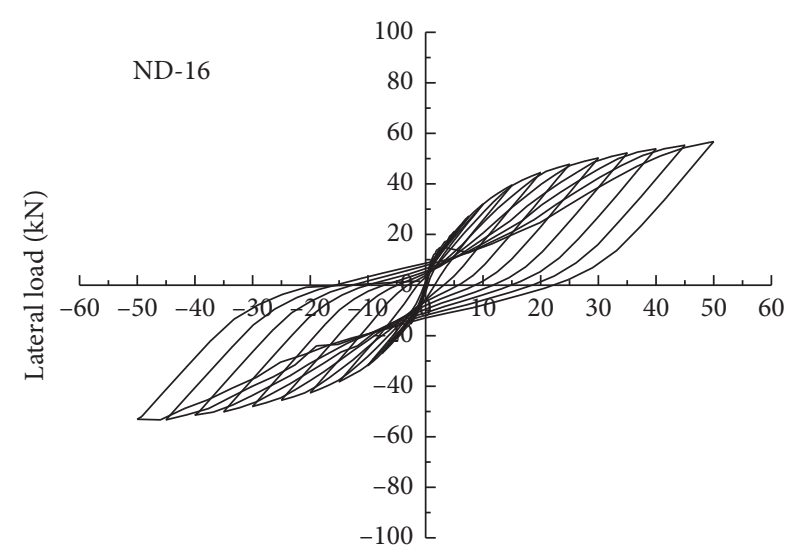

Displacement (mm)

(b)

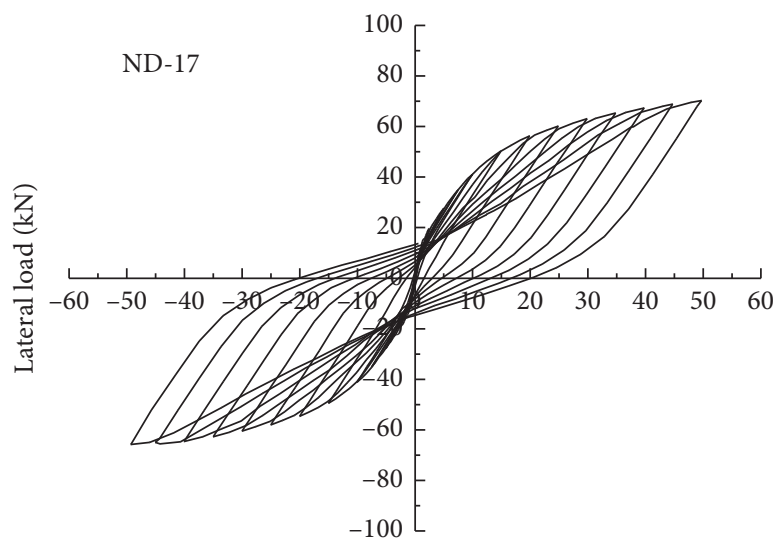

Displacement (mm)

(c)

Figure 16: Hysteretic curves of slit width $100 \mathrm{~mm}$. (a) $0.4 \mathrm{~mm}$. (b) $0.6 \mathrm{~mm}$. (c) $0.8 \mathrm{~mm}$.

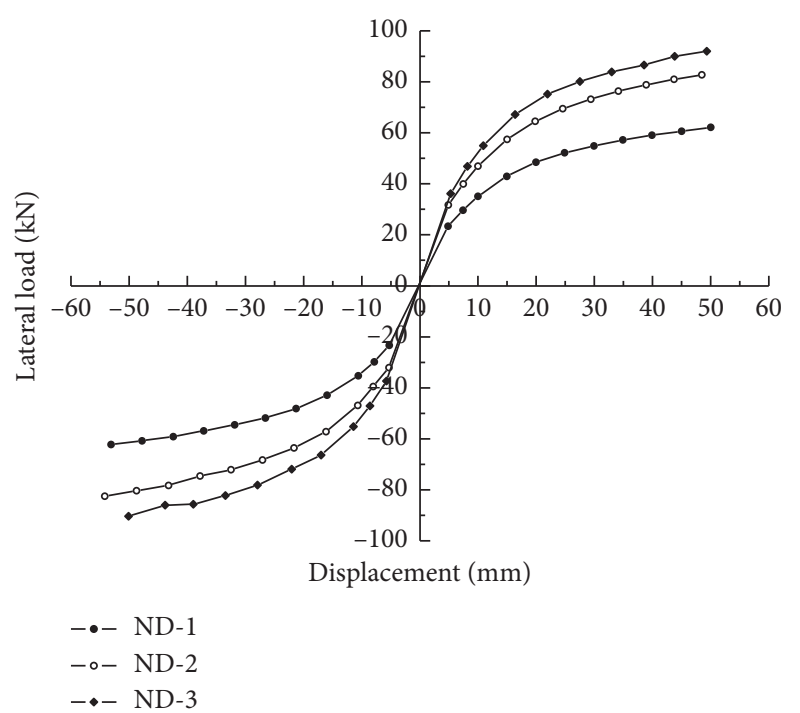

FIgURE 17: Skeleton curves of slit width $5 \mathrm{~mm}$.

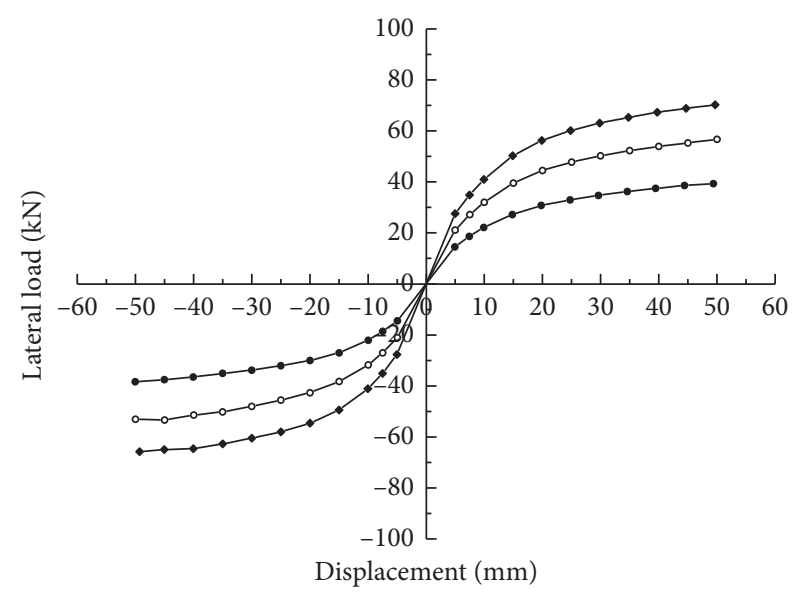

$$
\begin{aligned}
& -\bullet \text { ND-15 } \\
& \text {-॰- ND-16 } \\
& \text { - - ND-17 }
\end{aligned}
$$

Figure 18: Skeleton curves of slit width $100 \mathrm{~mm}$. 
TABLe 7: Loads, displacement, and ductility of different thickness.

\begin{tabular}{lccccccc}
\hline Specimen & Slit width $(\mathrm{mm})$ & Thickness & Yield load $(\mathrm{kN})$ & $\Delta \mathrm{y}(\mathrm{mm})$ & Ultimate load $(\mathrm{kN})$ & $\Delta \mathrm{u}(\mathrm{mm})$ & Ductility \\
\hline ND-1 & 5 & 0.4 & 38.97 & 11.92 & 60.14 & 49.99 \\
ND-2 & 5 & 0.6 & 49.45 & 10.97 & 80.68 & 48.49 \\
ND-3 & 5 & 0.8 & 55.02 & 10.92 & 92.03 & 4.42 \\
ND-15 & 100 & 0.4 & 28.21 & 15.25 & 39.34 & 49.35 \\
ND-16 & 100 & 0.6 & 39.56 & 15.23 & 56.73 & 49.35 \\
ND-17 & 100 & 0.8 & 50.3 & 14.89 & 70.24 & 50.01 & 3.24 \\
\hline
\end{tabular}

$\Delta_{y}$ : yield displacement; $\Delta_{u}$ : ultimate load.

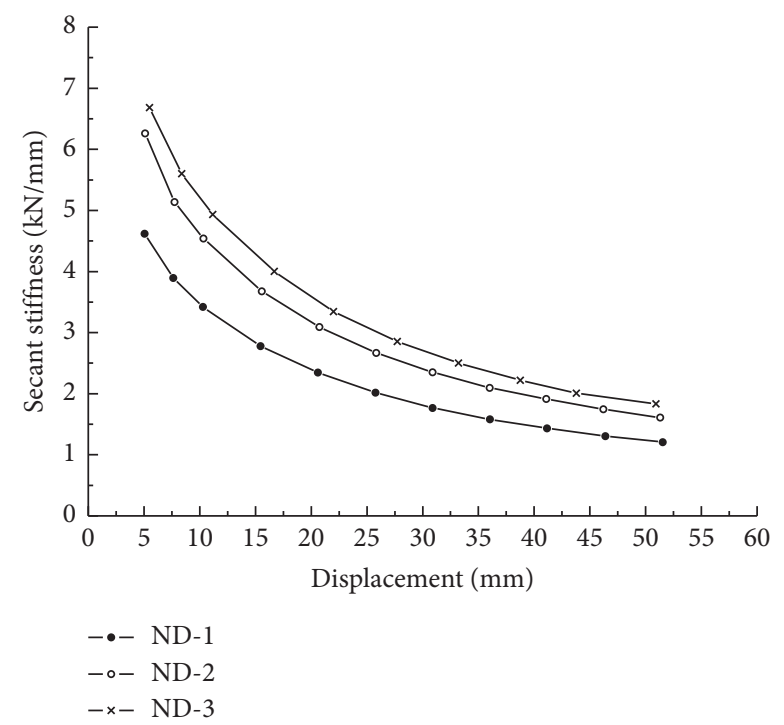

Figure 19: Stiffness curves of slit width $5 \mathrm{~mm}$.

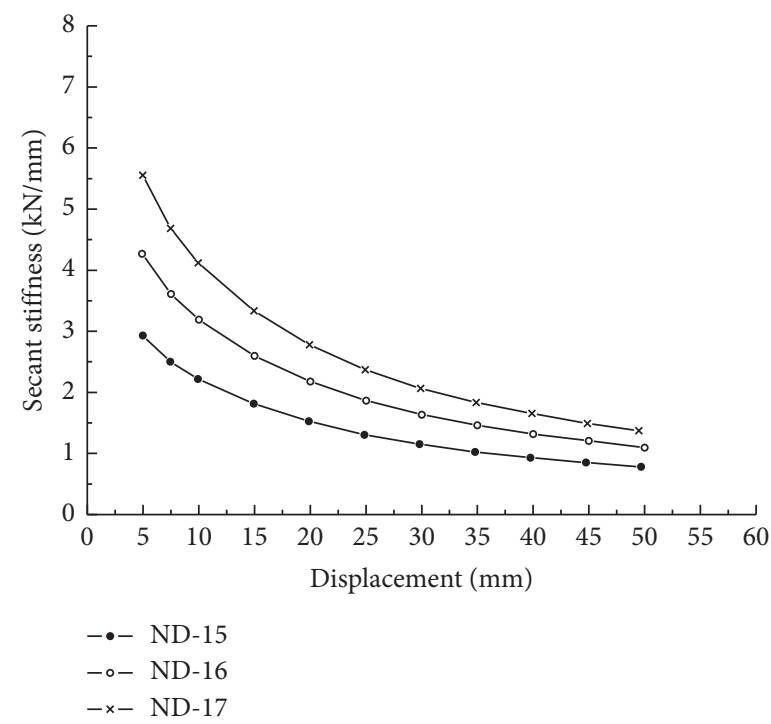

Figure 20: Stiffness curves of slit width $100 \mathrm{~mm}$.

TABLE 8: Stiffness of different thickness.

\begin{tabular}{lcccc}
\hline Specimen & Slit width $(\mathrm{mm})$ & Thickness $(\mathrm{mm})$ & Initial stiffness $(\mathrm{kN} / \mathrm{mm})$ & Ultimate stiffness $(\mathrm{kN} / \mathrm{mm})$ \\
\hline ND1 & 5 & 0.4 & 4.62 & 1.21 \\
ND2 & 5 & 0.6 & 6.26 & 1.61 \\
ND3 & 5 & 0.8 & 6.68 & 1.83 \\
ND15 & 100 & 0.4 & 2.93 & 0.78 \\
ND16 & 100 & 0.6 & 4.27 & 1.10 \\
ND17 & 100 & 0.8 & 5.55 & 1.38 \\
\hline
\end{tabular}


with columns only can be gained good stiffness. With the increase of thickness, the stiffness was enhanced largely.

\subsection{Concrete Strength}

5.3.1. Hysteretic Curves. The paper chose slit width $60 \mathrm{~mm}$ and $200 \mathrm{~mm}$ to investigate the influence of concrete strength. The concrete strength was $30 \mathrm{MPa}, 40 \mathrm{MPa}, 50 \mathrm{MPa}$ and $60 \mathrm{MPa}$. The hysteretic curves of slit width $60 \mathrm{~mm}$ and $200 \mathrm{~mm}$ are shown in Figures 21(a)-21(d) and 22(a)-22(d). Figures showed that the strength was improved as the increase of concrete strength. The energy dissipation had been enhanced when the concrete strength increased.

5.3.2. Skeleton Curves. The skeleton curves of slit width $60 \mathrm{~mm}$ and $200 \mathrm{~mm}$ are shown in Figures 23 and 24. Loads, displacement and ductility of different concrete strength are listed in Table 9. When the slit width was $60 \mathrm{~mm}$, the ultimate loads of concrete strength $40 \mathrm{MPa}, 50 \mathrm{MPa}$ and $60 \mathrm{MPa}$ were improved by $10.69 \%, 27.80 \%$ and $39.64 \%$ than that of concrete strength $30 \mathrm{MPa}$, respectively. When the slit width was $200 \mathrm{~mm}$, the ultimate loads of concrete strength $40 \mathrm{MPa}, 50 \mathrm{MPa}$ and $60 \mathrm{MPa}$ were improved by $17.90 \%$, $32.90 \%$ and $49.13 \%$ than that of concrete strength $30 \mathrm{MPa}$, respectively.

5.3.3. Ductility. The ductility of different concrete strength is presented in Table 9. It can be seen from the table that the ductility was enhanced with the increase of concrete strength. When the slit width was $60 \mathrm{~mm}$, the ductility was from 3.42 to 3.62 . When the slit width was $200 \mathrm{~mm}$, the ductility was from 3.26 to 3.65 . It indicated that the strengthened non-ductility RC frame earned good seismic performance in the scope of $60 \mathrm{MPa}$.

5.3.4. Stiffness Curves. The stiffness curves of slit width $60 \mathrm{~mm}$ and $200 \mathrm{~mm}$ are presented in Figures 25 and 26. The initial stiffness and ultimate stiffness of different concrete strength are presented in Table 10. The concrete strength $60 \mathrm{MPa}$ had the largest initial stiffness $5.93 \mathrm{kN} / \mathrm{mm}$ and the concrete strength $30 \mathrm{MPa}$ had the smallest initial stiffness $4.48 \mathrm{kN} / \mathrm{mm}$ when the slit width was $60 \mathrm{~mm}$. The concrete strength $60 \mathrm{MPa}$ had the largest initial stiffness $5.32 \mathrm{kN} / \mathrm{mm}$ and the concrete strength $30 \mathrm{MPa}$ had the smallest initial stiffness $4.32 \mathrm{kN} / \mathrm{mm}$ when the slit width was $200 \mathrm{~mm}$. The stiffness was increased by $32.37 \%$ and $23.15 \%$, respectively. It indicated that concrete strength influenced stiffness was not as large as the thickness parameter.

\subsection{Boundary Conditions}

5.4.1. Hysteretic Curves. The paper chose slit width $20 \mathrm{~mm}$, $30 \mathrm{~mm}, 40 \mathrm{~mm}$ and $300 \mathrm{~mm}$ to study the influence of boundary conditions. The boundary conditions were with and without $Z$-direction constraint on the edge of corrugated steel plate shear walls. The hysteretic curves of slit width $20 \mathrm{~mm}, 30 \mathrm{~mm}, 40 \mathrm{~mm}$ and $300 \mathrm{~mm}$ are shown in
Figures 27(a) and 27(b)-30(a) and 30(b). These figures indicated that the strength and energy dissipation were improved with $Z$-direction constraint. The $Z$-direction constrain transferred the internal shear better. It made better use of materials of the edge of corrugated steel plate shear walls.

5.4.2. Skeleton curves. The skeleton curves of slit width $20 \mathrm{~mm}, 30 \mathrm{~mm}, 40 \mathrm{~mm}$ and $300 \mathrm{~mm}$ are shown in Figures 31-34. Loads, displacement and ductility of different boundary conditions are listed in Table 11 . When the slit width was $20 \mathrm{~mm}$, the ultimate loads of $Z$-direction constrain was improved by $13.93 \%$ than that of non-constrain. When the slit width was $30 \mathrm{~mm}$, the ultimate loads of $Z$ direction constrain was improved by $9.26 \%$ than that of nonconstrain. When the slit width was $40 \mathrm{~mm}$, the ultimate loads of $Z$-direction constrain was improved by $11.91 \%$ than that of non-constrain. When the slit width was $300 \mathrm{~mm}$, the ultimate loads of $Z$-direction constrain was improved by $27.71 \%$ than that of non-constrain.

5.4.3. Ductility. The ductility of different boundary conditions is presented in Table 11. It can be seen from the table that the ductility was improved with $Z$-direction constrain. However, the enhancement was not so obvious. The improved range was $1.71 \%, 1.69 \%, 0.57 \%$ and $2.88 \%$, respectively. It indicated that changing the boundary conditions had little effect on ductility.

5.4.4. Stiffness Curves. The stiffness curves of slit width $20 \mathrm{~mm}, 30 \mathrm{~mm}, 40 \mathrm{~mm}$ and $300 \mathrm{~mm}$ are presented in Figures 35-38. The initial stiffness and ultimate stiffness of different boundary conditions are presented in Table 12. It can be seen from the table that the $Z$-direction constraint was improved $13.23 \%, 13.81 \%, 7.80 \%, 27.49 \%$ than that of non-constraint, respectively. The trend of stiffness curves were in accordance with each other. The improved amplitude was not a large increase.

5.5. Explanation of Slotted Principle. The proposed slotted principle was based on the following principles. When shear walls adopt plain plate, the shear buckling tends to occur at lower lateral forces. Then shear walls take lateral loads through oblique tension band action. The columns anchor the oblique tension band while the tension belt also causes a relatively high additional bending moment to the columns [22].

The proposed corrugated steel plate shear walls have ribs on the surface, which improves buckling strength prominently. It solves the buckling of plain plate easily. Through the analysis of each parameter in the paper, it can be seen that corrugated steel plate shear walls transmit force in the form of in-plane shear. The force form accords with the slotted principle. Strength, ductility, stiffness, and energy dissipating perform well within a reasonable slit range. The nonductile RC frame gained good seismic performance. 


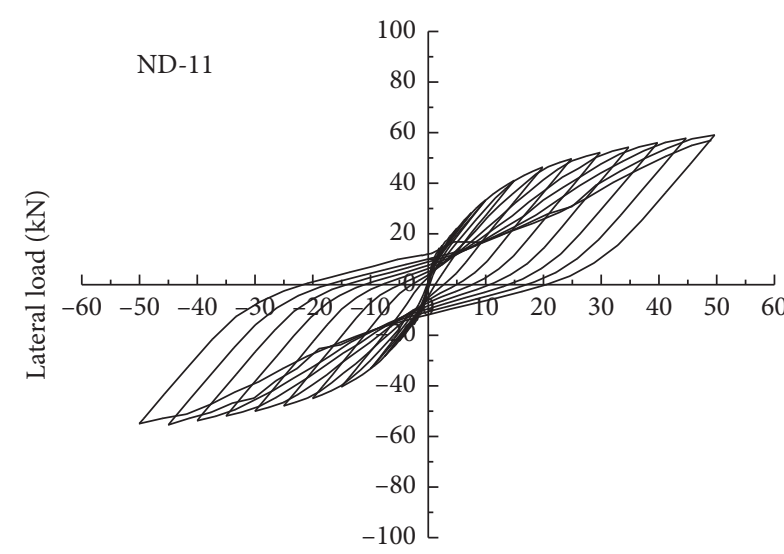

Displacement $(\mathrm{mm})$

(a)

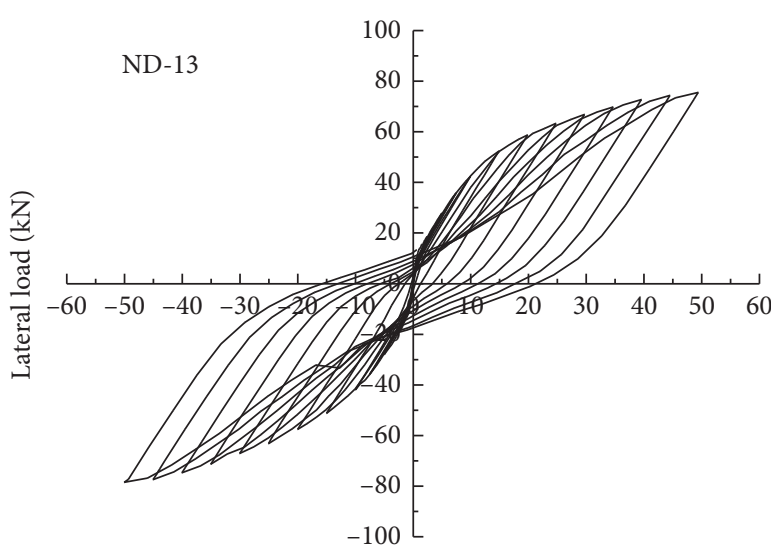

Displacement (mm)

(c)

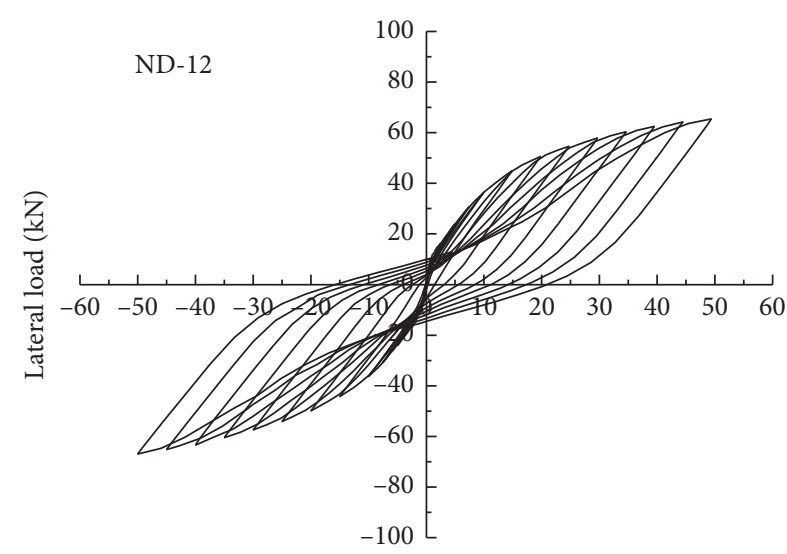

Displacement $(\mathrm{mm})$

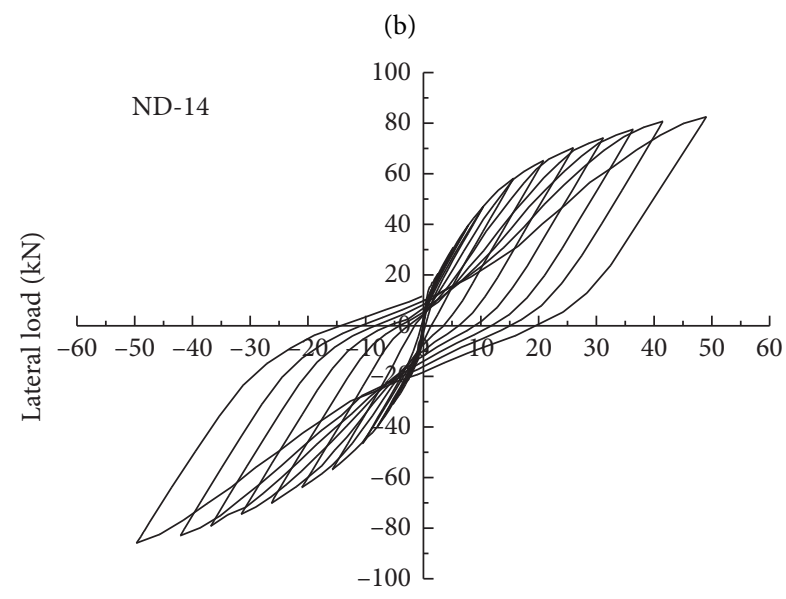

Displacement $(\mathrm{mm})$

(d)

Figure 21: Hysteretic curves of slit width $60 \mathrm{~mm}$. (a) $30 \mathrm{MPa}$. (b) $40 \mathrm{MPa}$. (c) $50 \mathrm{MPa}$. (d) $60 \mathrm{MPa}$

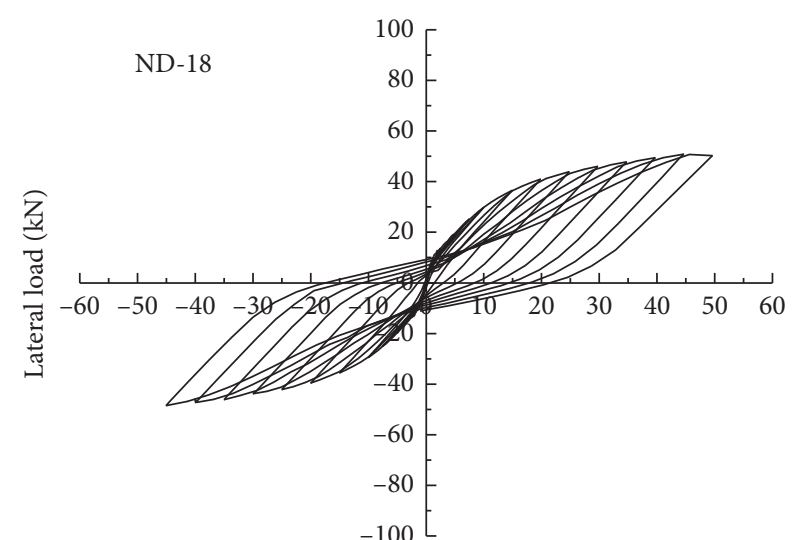

Displacement $(\mathrm{mm})$

(a)

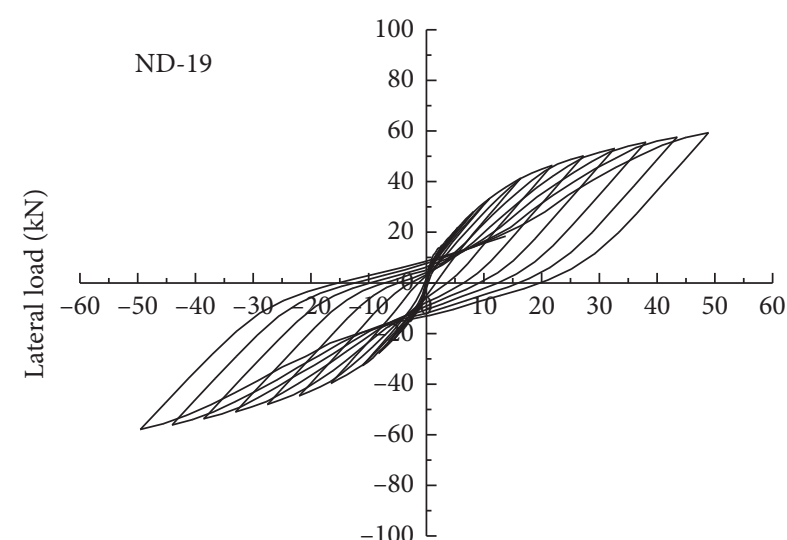

Displacement (mm)

(b)

Figure 22: Continued. 


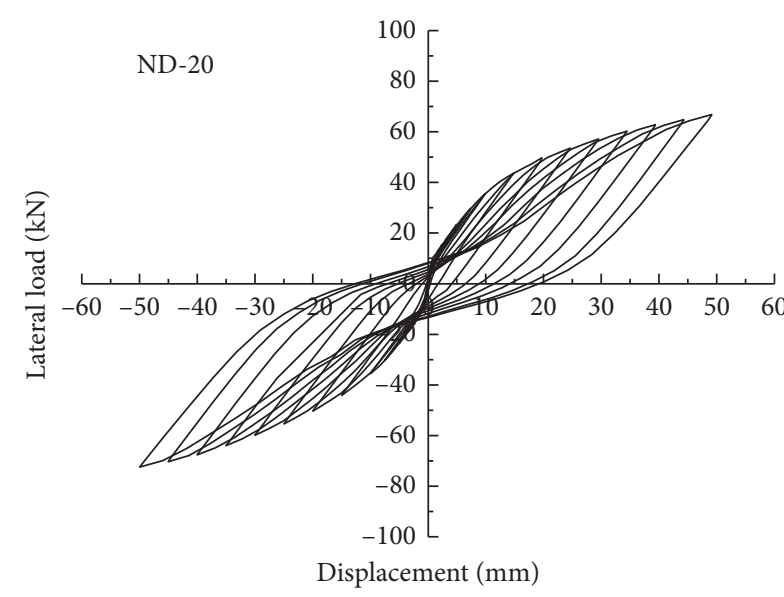

(c)

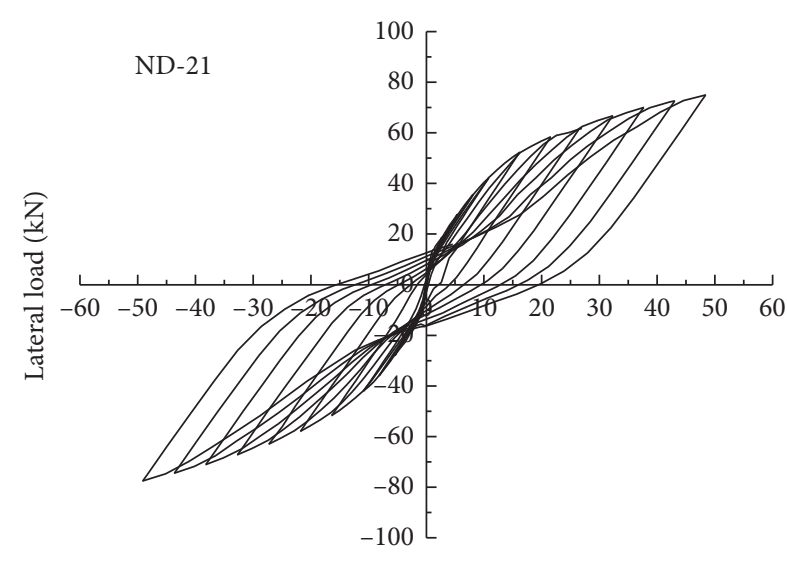

Displacement (mm)

(d)

Figure 22: Hysteretic curves of slit width $200 \mathrm{~mm}$. (a) $30 \mathrm{MPa}$. (b) $40 \mathrm{MPa}$. (c) $50 \mathrm{MPa}$. (d) $60 \mathrm{MPa}$.

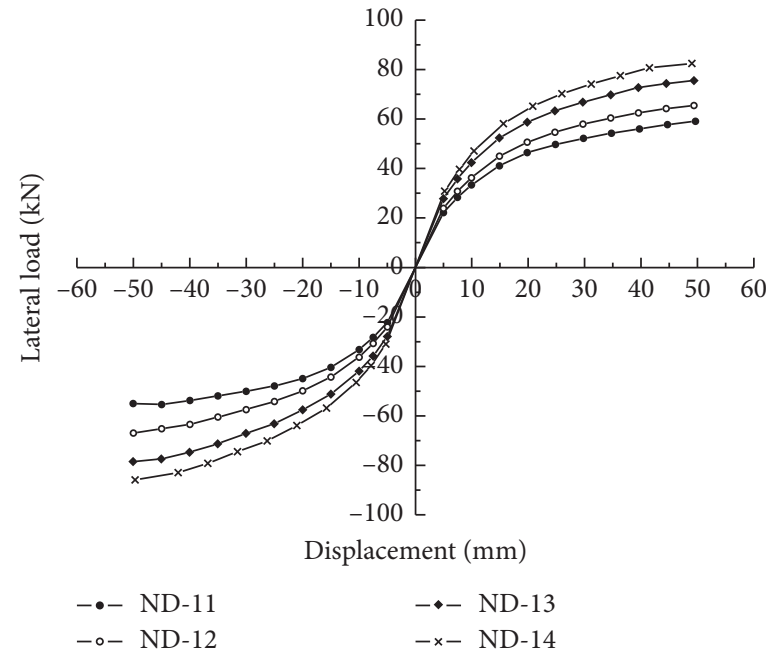

Figure 23: Skeleton curves of slit width $60 \mathrm{~mm}$.

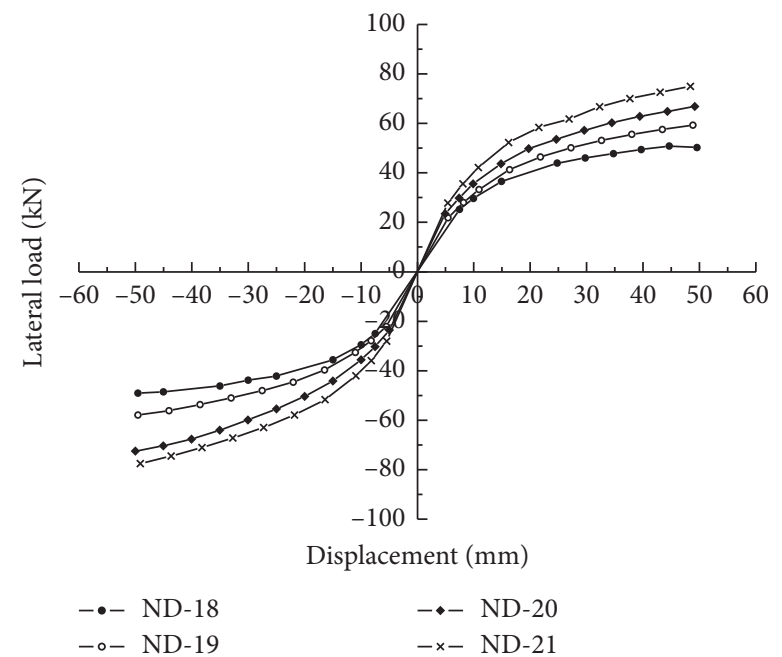

FIgURE 24: Skeleton curves of slit width $200 \mathrm{~mm}$. 
TABLE 9: Loads, displacement and ductility of different concrete strength.

\begin{tabular}{|c|c|c|c|c|c|c|c|}
\hline Specimen & Slit width $(\mathrm{mm})$ & Concrete strength (MPa) & Yield load $(\mathrm{kN})$ & $\Delta_{y}(\mathrm{~mm})$ & Ultimate load $(\mathrm{kN})$ & $\Delta_{u}(\mathrm{~mm})$ & Ductility \\
\hline ND11 & 60 & 30 & 40.97 & 14.51 & 59.11 & 49.631 & 3.42 \\
\hline ND12 & 60 & 40 & 44.65 & 14.27 & 65.43 & 49.392 & 3.46 \\
\hline ND13 & 60 & 50 & 51.36 & 13.89 & 75.54 & 49.394 & 3.56 \\
\hline ND14 & 60 & 60 & 52.78 & 13.55 & 82.54 & 49.025 & 3.62 \\
\hline ND18 & 200 & 30 & 37.86 & 15.22 & 50.27 & 49.57 & 3.26 \\
\hline ND19 & 200 & 40 & 39.59 & 14.76 & 59.27 & 48.87 & 3.31 \\
\hline ND20 & 200 & 50 & 43.09 & 14.21 & 66.81 & 49.19 & 3.46 \\
\hline ND21 & 200 & 60 & 47.77 & 13.26 & 74.97 & 48.39 & 3.65 \\
\hline
\end{tabular}

$\Delta_{y}:$ Yield displacement; $\Delta_{u}$ : Ultimate load.

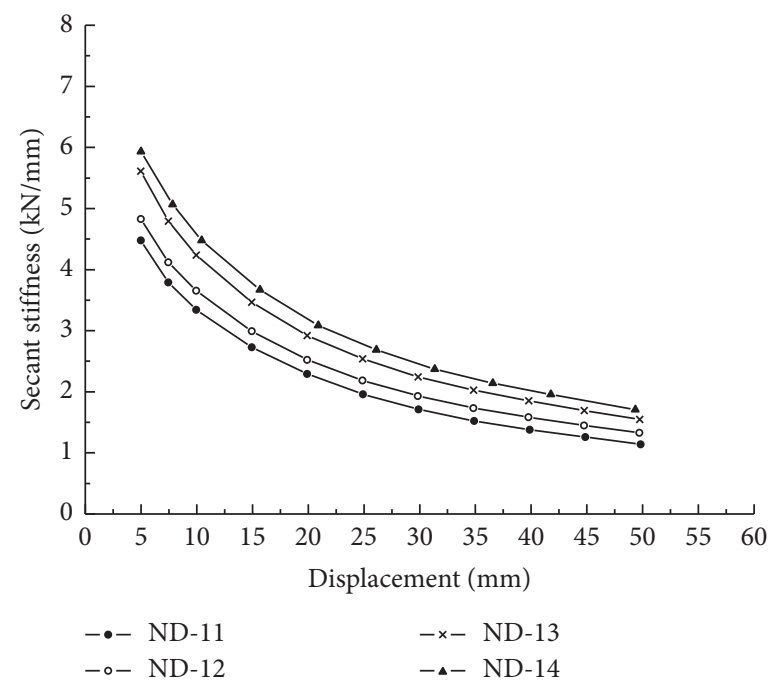

Figure 25: Stiffness curves of slit width $60 \mathrm{~mm}$.

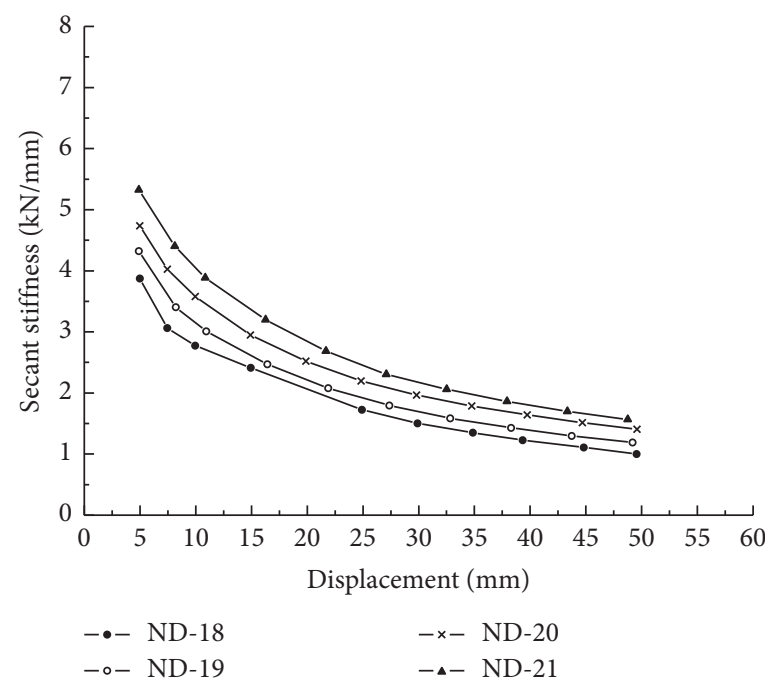

FIgURE 26: Stiffness curves of slit width $200 \mathrm{~mm}$. 
TABLE 10: Stiffness of different concrete strength.

\begin{tabular}{lcccc}
\hline Specimen & Slit width $(\mathrm{mm})$ & Thickness $(\mathrm{mm})$ & Initial stiffness $(\mathrm{kN} / \mathrm{mm})$ & Ultimate stiffness $(\mathrm{kN} / \mathrm{mm})$ \\
\hline ND11 & 60 & 30 & 4.48 & 1.15 \\
ND12 & 60 & 40 & 4.83 & 1.33 \\
ND13 & 60 & 50 & 5.61 & 1.55 \\
ND14 & 60 & 60 & 5.93 & 1.71 \\
ND18 & 200 & 30 & 3.87 & 1.01 \\
ND19 & 200 & 40 & 4.32 & 1.19 \\
ND20 & 200 & 50 & 4.74 & 1.40 \\
ND21 & 200 & 60 & 5.32 & 1.56 \\
\hline
\end{tabular}

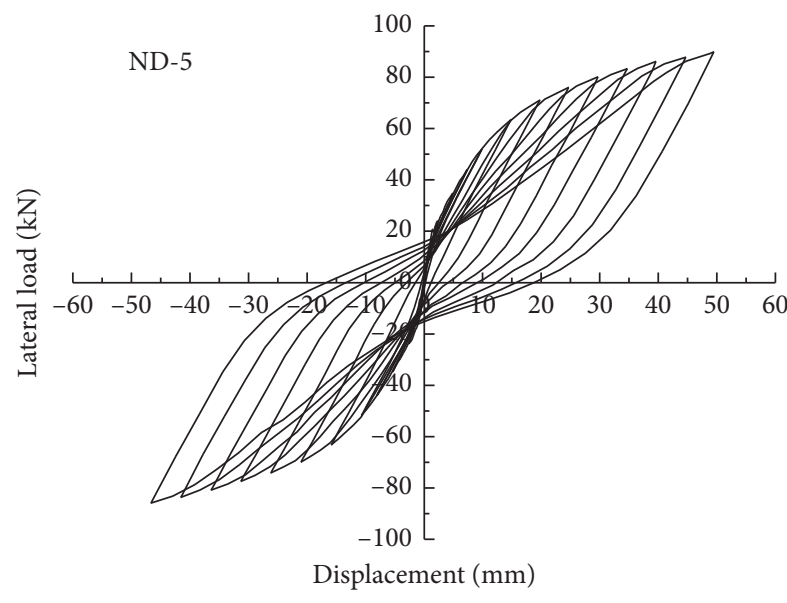

(a)

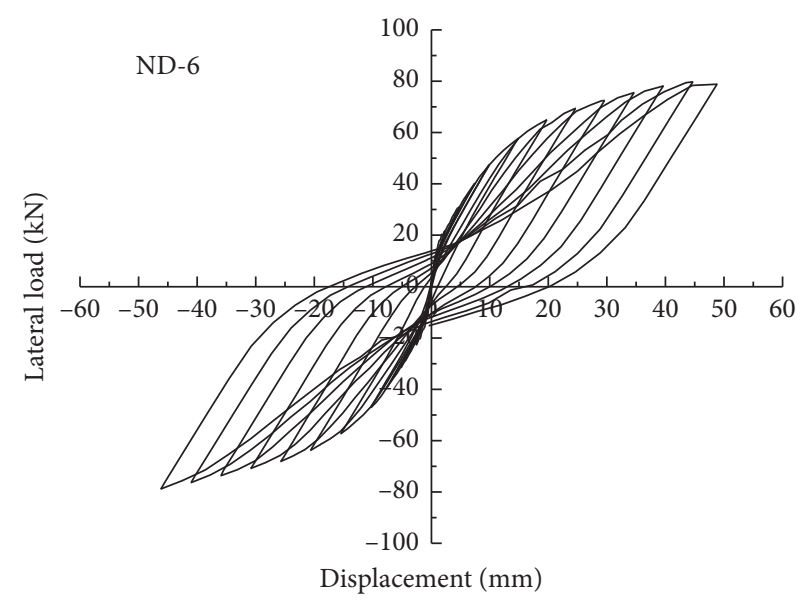

(b)

FIgURE 27: Hysteretic curves of Slit width $20 \mathrm{~mm}$. (a) Z-direction constrain. (b) Without constrain.

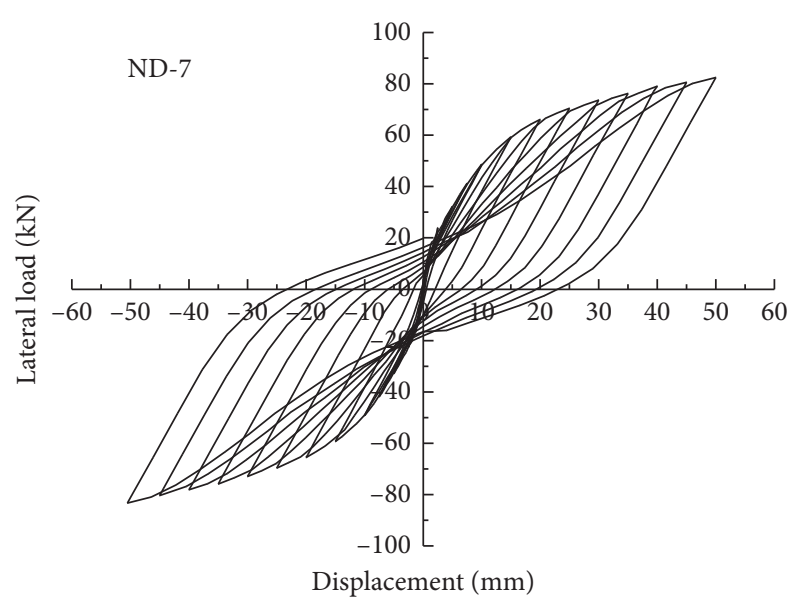

(a)

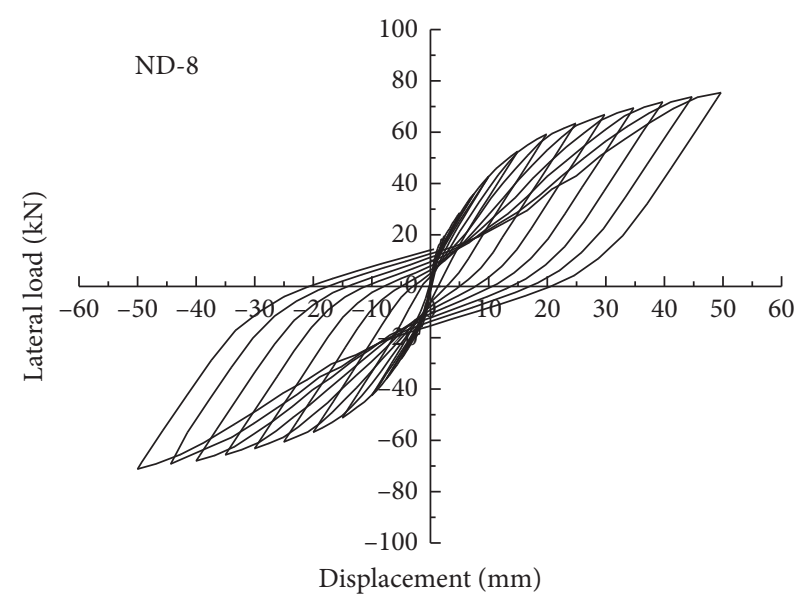

(b)

FIgURE 28: Hysteretic curves of Slit width $30 \mathrm{~mm}$. (a) Z-direction constrain. (b) Without constrain. 


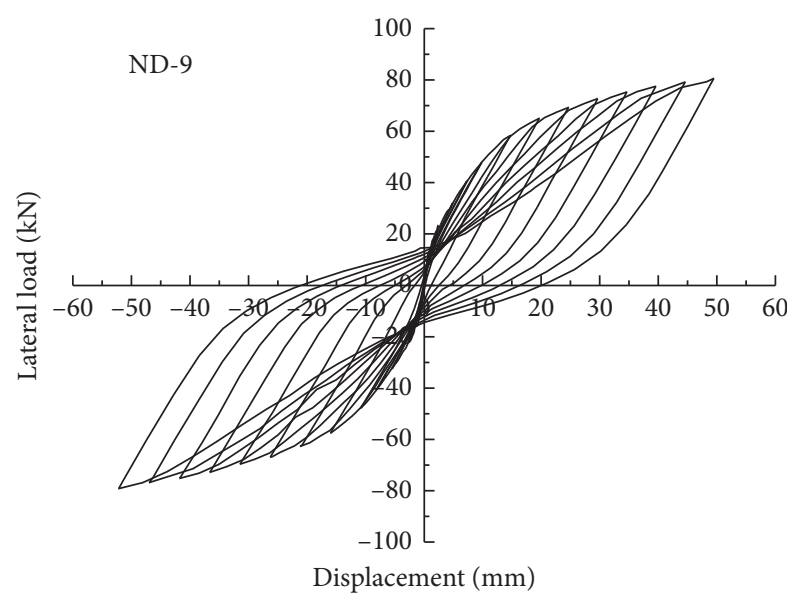

(a)

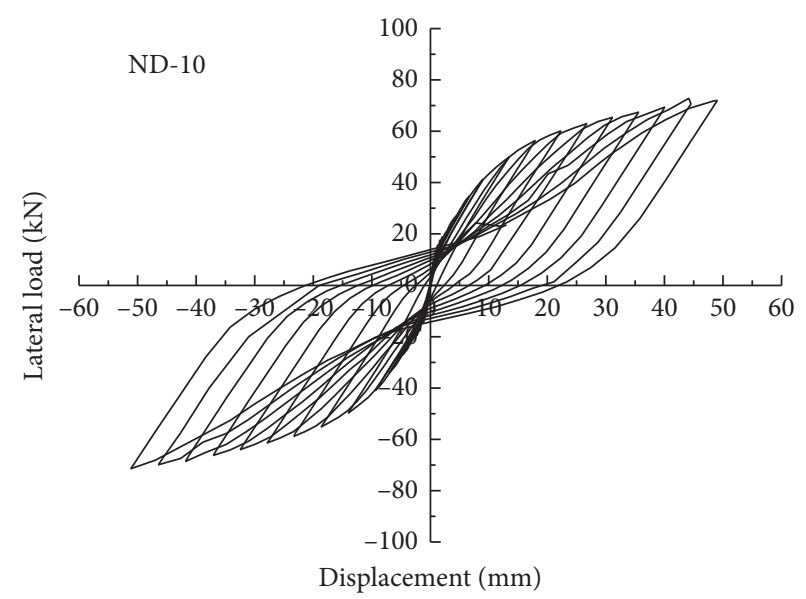

(b)

FIgURE 29: Hysteretic curves of Slit width $40 \mathrm{~mm}$. (a) Z-direction constrain. (b) Without constrain.

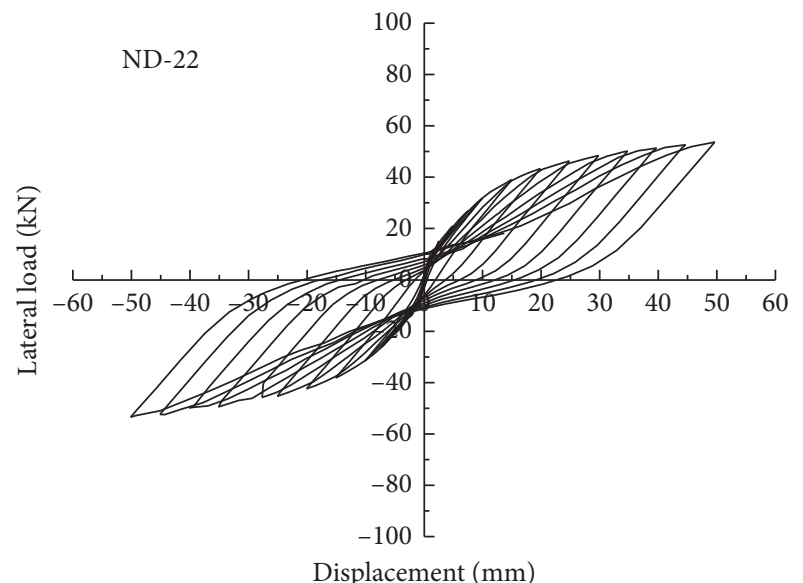

(a)

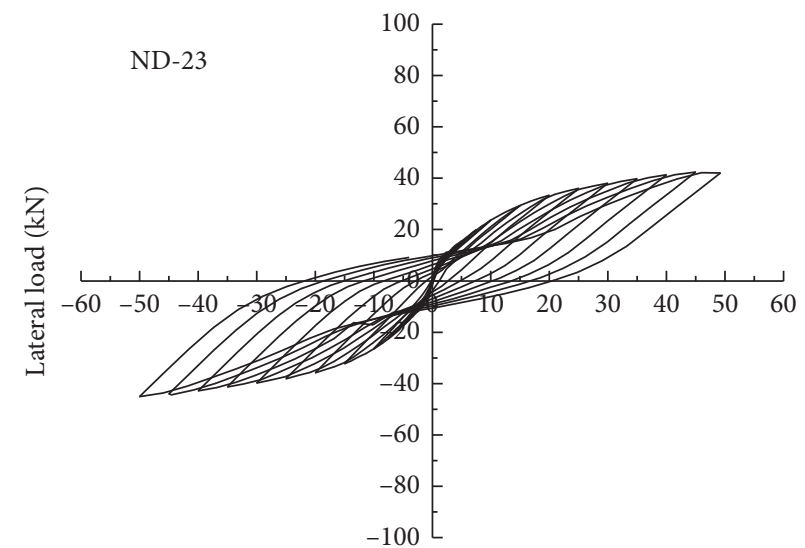

Displacement (mm)

(b)

Figure 30: Hysteretic curves of Slit width $300 \mathrm{~mm}$. (a) Z-direction constrain. (b) Without constrain.

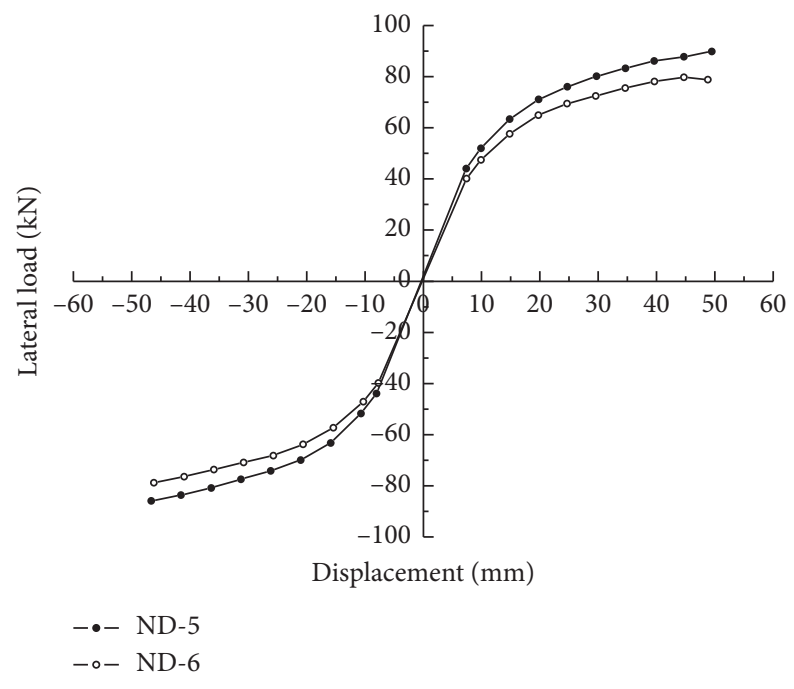

FIGURE 31: Skeleton curves of slit width $20 \mathrm{~mm}$. 


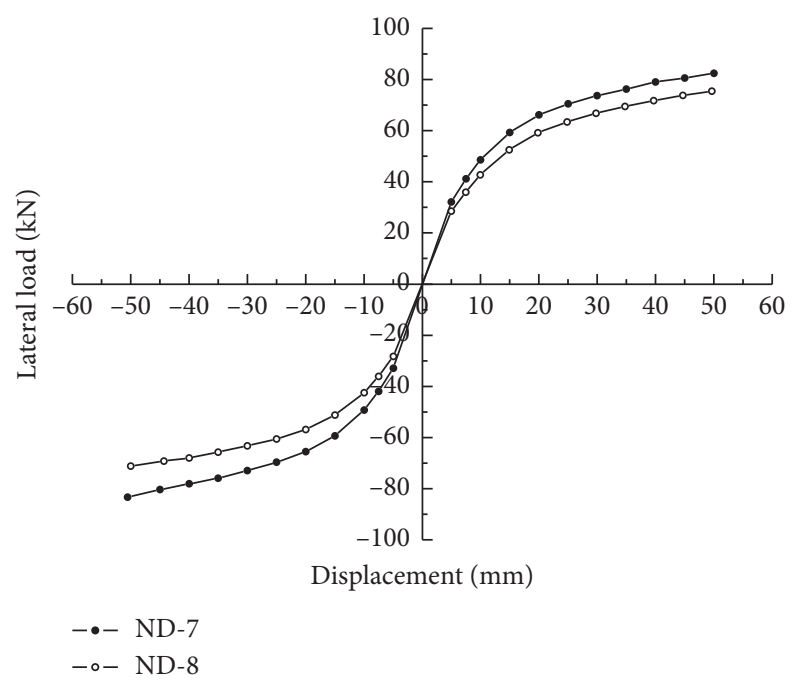

Figure 32: Skeleton curves of slit width $30 \mathrm{~mm}$.

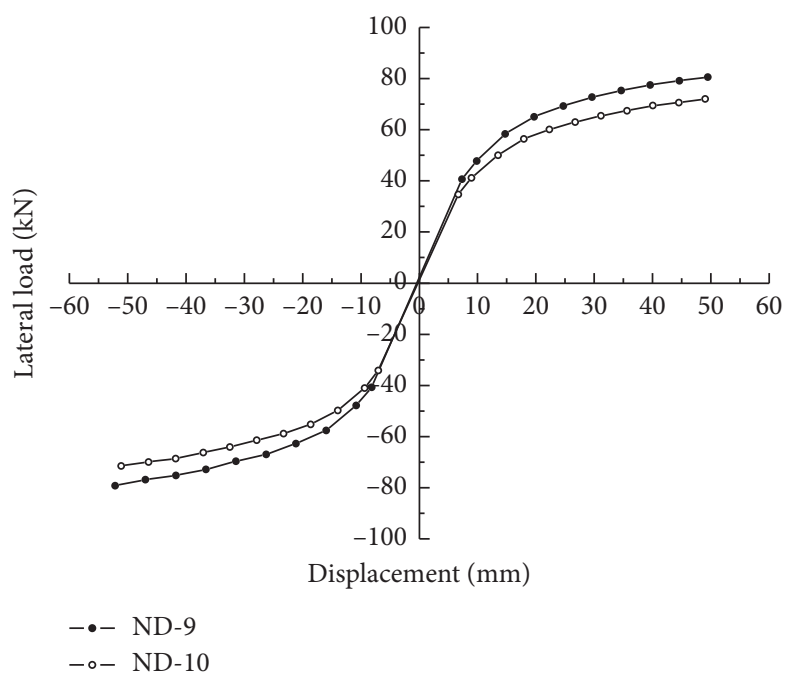

Figure 33: Skeleton curves of slit width $40 \mathrm{~mm}$.

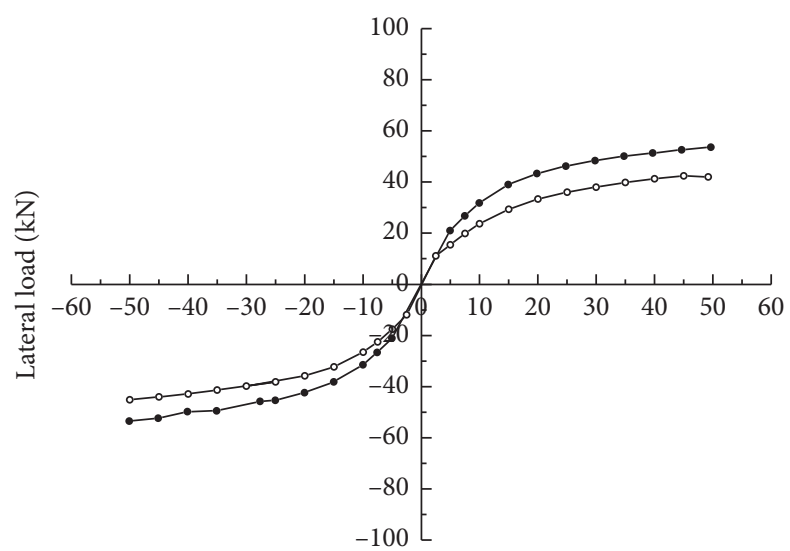

Displacement (mm)

$-\bullet-\mathrm{ND}-22$

-。- ND-23

FIgURE 34: Skeleton curves of slit width $300 \mathrm{~mm}$. 
TABLE 11: Loads, displacement and ductility of different boundary conditions.

\begin{tabular}{|c|c|c|c|c|c|c|c|}
\hline Specimen & Slit width $(\mathrm{mm})$ & Boundary conditions & Yield load $(\mathrm{kN})$ & $\Delta_{y}(\mathrm{~mm})$ & Ultimate load $(\mathrm{kN})$ & $\Delta_{u}(\mathrm{~mm})$ & Ductility \\
\hline ND5 & 20 & $\mathrm{UZ}$ & 62.39 & 13.58 & 89.86 & 49.48 & 3.64 \\
\hline ND6 & 20 & - & 56.82 & 13.64 & 78.87 & 48.83 & 3.58 \\
\hline ND7 & 30 & UZ & 53.61 & 13.87 & 82.44 & 50.05 & 3.61 \\
\hline ND8 & 30 & - & 51.76 & 13.98 & 75.45 & 49.63 & 3.55 \\
\hline ND9 & 40 & UZ & 57.93 & 14.09 & 80.60 & 49.47 & 3.51 \\
\hline ND10 & 40 & - & 51.59 & 14.05 & 72.02 & 49.04 & 3.49 \\
\hline ND22 & 300 & UZ & 39.24 & 15.41 & 53.65 & 49.62 & 3.22 \\
\hline ND23 & 300 & 一 & 29.47 & 15.73 & 42.01 & 49.24 & 3.13 \\
\hline
\end{tabular}

$\Delta_{y}$ : Yield displacement; $\Delta_{u}$ : Ultimate load.

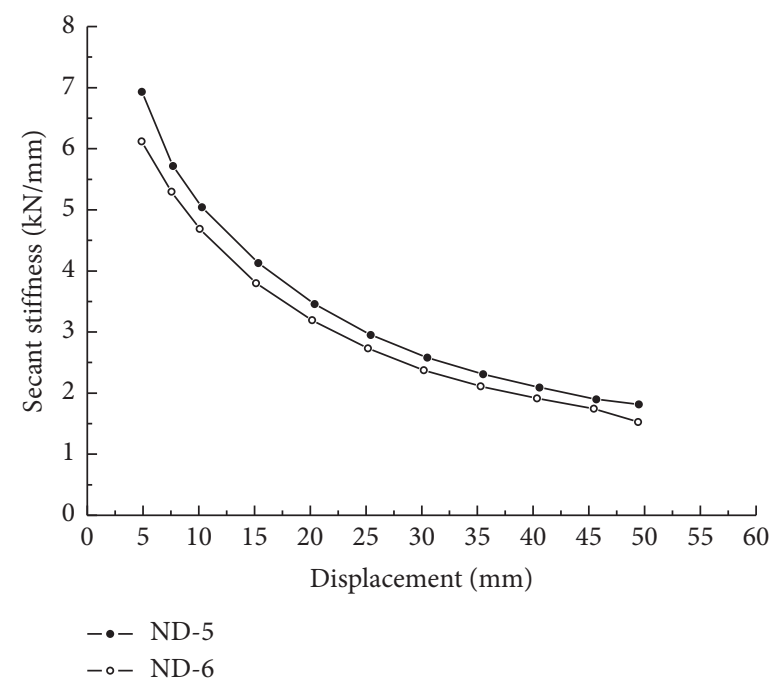

FIGURE 35: Stiffness curves of slit width $20 \mathrm{~mm}$.

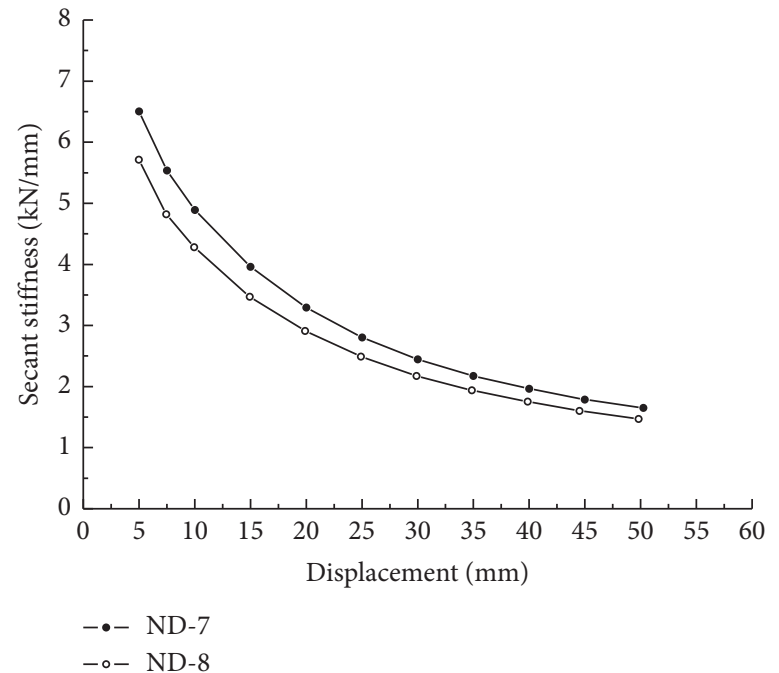

Figure 36: Stiffness curves of slit width $30 \mathrm{~mm}$. 


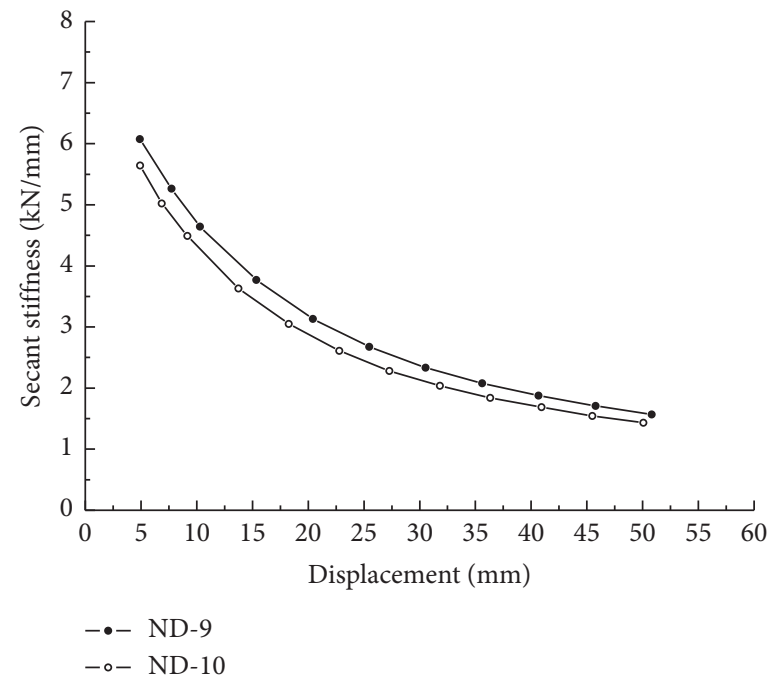

FIgURE 37: Stiffness curves of slit width $40 \mathrm{~mm}$.

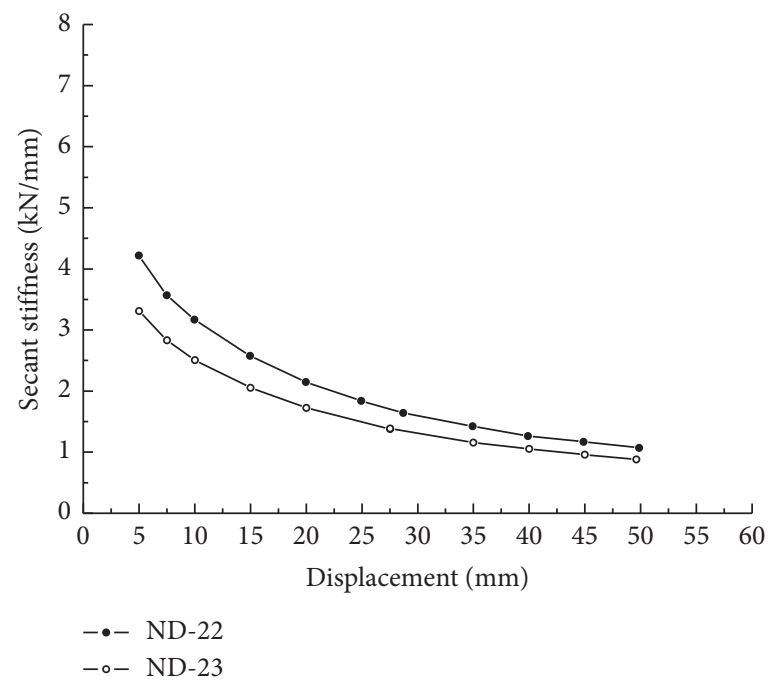

FIgURE 38: Stiffness curves of slit width $300 \mathrm{~mm}$.

TABLE 12: Stiffness of different boundary conditions.

\begin{tabular}{lcccc}
\hline Specimen & Slit width $(\mathrm{mm})$ & Thickness $(\mathrm{mm})$ & Initial stiffness $(\mathrm{kN} / \mathrm{mm})$ & Ultimate stiffness $(\mathrm{kN} / \mathrm{mm})$ \\
\hline ND5 & 20 & $\mathrm{UZ}$ & 6.93 & 1.82 \\
ND6 & 20 & - & 6.12 & 6.51 \\
ND7 & 30 & $\mathrm{UZ}$ & 5.72 & 1.65 \\
ND8 & 30 & $\mathrm{UZ}$ & 6.08 & 1.47 \\
ND9 & 40 & - & 5.64 & 1.57 \\
ND10 & 40 & $\mathrm{UZ}$ & 4.22 & 1.43 \\
ND22 & 300 & - & 3.31 & 1.07 \\
ND23 & 300 & & 0.88 \\
\hline
\end{tabular}

\section{Conclusions}

Two specimens, Specimen ND-1 and Specimen ND-2, are compared. There were 24 models to research the seismic behavior on different influence parameters. The parameters are slit width, thickness of corrugated steel plate shear walls, concrete strength of nonductile RC frame, and boundary conditions of corrugated steel plate shear walls at slotted 
parts. Hysteresis curves, skeleton curves, ductility, and stiffness curves were researched in the paper. The following conclusions can be drawn:

(i) To verify the availability of the models, the simulated results were compared with experimental results. The effective model indicated that the corrugated steel plate shear walls slotted with columns played a positive role in seismic behavior.

(ii) The paper selected four slit widths $(10 \mathrm{~mm}, 100 \mathrm{~mm}$, $200 \mathrm{~mm}$, and $400 \mathrm{~mm}$ ) to study the seismic performance of reinforced nonductile RC frame. Hysteresis curves and skeleton curves manifested that the strength was declined when the slit width was larger. Ductility had been improved in the strengthening with corrugated steel plate shear walls. Ductility was above 3.0 and the ductility was larger with the slit width being smaller. Stiffness was enhanced with the decrease of slit width.

(iii) With the thickness of corrugated steel plate shear walls increasing, the strength, ductility, stiffness, and energy dissipating capacity were enhanced greatly. The reinforced nonductile RC frame had enough seismic performance.

(iv) With concrete strength increasing, the strength and stiffness were enhanced gradually. The influence of concrete strength on ductility was little.

(v) Boundary conditions of corrugated steel plate shear walls at slotted parts were an important influence on nonductile RC frame. With the boundary conditions, larger strength, ductility, and stiffness can be gained. However, the increase was not very significant.

(vi) When the slit width was within the scope of $300 \mathrm{~mm}$, the seismic behavior of nonductile RC frame slotted with corrugated steel plate shear walls could gain good performance.

\section{Data Availability}

All relevant data used in this study are within the paper and its Optional Supplementary Materials.

\section{Conflicts of Interest}

The authors declare that they have no conflicts of interest.

\section{Acknowledgments}

The authors would like to acknowledge the Natural Science Foundation of the Jiangsu Higher Education Institutions of China (No. 18KJB560002), the Research Project of Ministry of Housing and Urban-Rural Development of Jiangsu province (No. 2017ZD233), Research Project of Changzhou Institute of Technology (No. YN1722), the Project of Changzhou Science and Technology Program (No. CE20195034), the Project of Undergraduate Training Program for Innovation and Entrepreneurship (Nos. 2019064Z and 202011055051Y), and the
Research Project of Changzhou Institute of Technology (No. YN20019).

\section{References}

[1] P. Z. Zhang and J. P. Ou, "Seismic performance analysis and evaluation for low-ductile RC frame structures," Journal of Building Structures, vol. 34, no. 12, pp. 11-18, 2013, in Chinese.

[2] K. J. Elwood, "Modelling failures in existing reinforced concrete columns," Canadian Journal of Civil Engineering, vol. 31, no. 5, pp. 846-859, 2004.

[3] S. Yavari, K. J. Elwood, and C.-1. Wu, "Collapse of a nonductile concrete frame: evaluation of analytical models," Earthquake Engineering and Structural Dynamics, vol. 38, no. 2, pp. 225-241, 2009.

[4] C.-1. Wu, W.-W. Kuo, Y.-S. Yang et al., "Collapse of a nonductile concrete frame: shaking table tests," Earthquake Engineering and Structural Dynamics, vol. 38, no. 2, pp. 205-224, 2009.

[5] C. D. Comartin, T. Anagnos, H. Faison, M. Greene, and J. Moehle, "The concrete coalition: building a network to address nonductile concrete buildings," in Proceedings of the 14th World Conference On Earthquake Engineering: Innovation Practice Safety, International Association for Earthquake Engineering, Beijing, China, October 2008.

[6] M. B. Shoraka, Collapse assessment of non-ductile reinforced concrete moment frames, Ph.D. Dissertation, Department of Civil Engineering, University of British Columbia, Vancouver, BC, Canada, 2012.

[7] H. Aslani and E. Miranda, "Fragility assessment of slabcolumn connections in existing non-ductile reinforced concrete buildings," Journal of Earthquake Engineering, vol. 9, no. 6, pp. 755-775, 2005.

[8] E. F. Deng, L. Zong, and Y. Ding, "Numerical and analytical study on initial stiffness of corrugated steel plate shear walls in modular construction," Steel and Composite Structures, vol. 32, no. 3, pp. 347-359, 2019.

[9] M. Shariati, "Numerical study on the structural performance of corrugated low yield point steel plate shear walls with circular openings," Steel and Composite Structures, vol. 33, no. 4, pp. 569-581, 2019.

[10] W. J. Wu, W. X. Song, and S. F. Jiang, "Multi-scale modeling and seismic performance analysis on non-ductile frame structures," Journal of Basic Science and Engineering, vol. 26, no. 6, pp. 164-174, 2018, in Chinese.

[11] W. Sae-Long, S. Limkatanyu, and W. Prachasaree, "Nonlinear frame element with shear- flexure interaction for seismic analysis of non-ductile reinforced concrete columns," International Journal of Concrete Structures and Materials, vol. 13, no. 1, pp. 13-32, 2019.

[12] M. B. Shoraka, T. Y. Yang, and K. J. Elwood, "Seismic loss estimation of non-ductile reinforced concrete buildings," Earthquake Engineering and Structural Dynamics, vol. 42, no. 2, pp. 297-310, 2013.

[13] L. L. Song and M. Ezechia, "Study on seismic performance of non-ductile RC frames retrofitted by SMA braces," Building Structure, vol. 48, no. S2, pp. 761-764, 2018, in Chinese.

[14] A. Khampanit, S. Leelataviwat, J. Kochanin, and P. Warnitchai, "Energy-based seismic strengthening design of non-ductile reinforced concrete frames using buckling-restrained braces," Engineering Structures, vol. 81, no. 1, pp. 110-122, 2014.

[15] L. D. Sarno and G. Manfredi, "Seismic retrofitting with buckling restrained braces: application to an existing non- 
ductile RC framed building," Soil Dynamicsand Earthquake Engineering, vol. 30, no. 11, pp. 1279-1297, 2010.

[16] W. H. Chen, Z. H. Qiao, and W. R. Shou, "Experimental study on seismic performance of CFRP-retrofitted earthquake damaged non-ductile RC frames," Journal of Southwest Jiaotong University, vol. 1, no. 5, pp. 1-8, 2019, in Chinese.

[17] D. G. Lv, X. H. Yu, and N. Li, "Seismic collapse fragility analysis for non-ductile RC frame structures retrofitted with FRP," Journal of Building Structures, vol. 36, no. S2, pp. 112-118, 2015, in Chinese.

[18] F. W. Qiu and P. Pan, "Quasi-static loading and control for structural test," Chinese Journal of Civil Engineering, vol. 35, no. 1, pp. 1-10, 2002, in Chinese.

[19] N. Feng, C. Wu, and P. Cao, "Seismic performance of infilled RC frames with steel corrugated shear walls," Magazine of Concrete Research, vol. 72, no. 11, pp. 541-551, 2020.

[20] Q. H. Zhao, J. Qiu, B. C. Hao et al., "Lateral behavior of vertically-corrugated steel plate shear walls connected with beams only," Journal of Tianjin University(Science and Technology), vol. 52, no. S2, pp. 46-53, 2019.

[21] N. Feng, P. Cao, K. Wu, and P. Zhang, "Experimental investigation on strengthening of infilled frame structures by profiled steel sheet shear walls," Advances in Structural Engineering, vol. 19, no. 4, pp. 703-714, 2016.

[22] Design code, AISC Steel Design Guide 20: Steel Plate Shear Walls, AISC, Chicago, IL, USA, 2006. 